
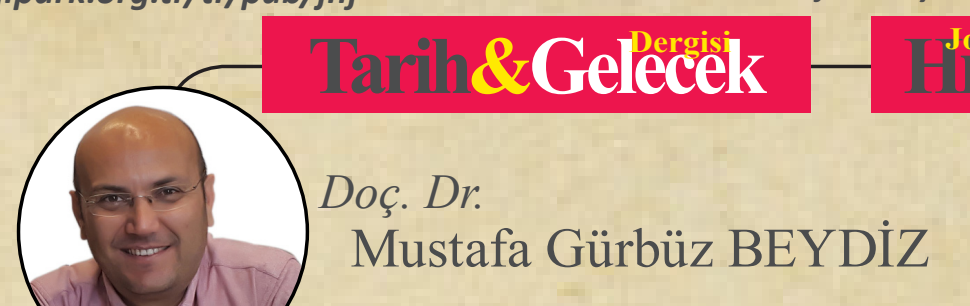

Mustafa Gürbüz BEYDİZ

ORCID:

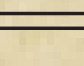

Eser Geçmişi / Article Past:

Araştırma Makalesi

DOI: http://dx.doi.org/10.21551/jhf.914029
Çankırı Karatekin Üniversitesi, Sanat, Tasarım ve Mimarlık Fakültesi, Temel Sanat Bilimleri Bölümü, Çankırı, Türkiye, beydizg@gmail.com

\section{\&Evuture}

. Cite

Research Paper

ideal

\title{
Türk İmgesinin Başlangıcından Batılılaşma Dönemine Kadar Fizyolojik Açıdan ve Giyim-Kuşam Bağlamında Değerlendirilmesi
}

\author{
Evaluation of the Turkish Image from Beginning to the \\ Westernization Period in Terms of Physiological and in the \\ Context of Clothes-Apparel
}

\section{$\ddot{O} z$}

Avrupa'nın birçok yerinde Türk imajı üzerine yapılmış sanat eserlerine rastlamak mümkündür. Resimden heykele sanatına kadar farklı sanat eserlerinde izlenen bu betimlemeler çeşitli türlerde görülmektedir. Bu araştırmada Türk imgesinin Avrupa'da özellikle XVI ile XVIII. yüzyılları arasında görülen etkisi üzerine durulmuştur. Ayrıca, figürlerin hem yüz anatomileri, saç ve sakal tarzları hem de kıyafetleri incelendiğinde Avrupa sanatında Türk imgesinin tam ne olduğu sorusuna cevap aranmıştır. Doğunun gizemli ve zengin kültürü batıyı etkilemiştir ancak doğunun yerel öz kültürünü görmeden, hissetmeden yapılan her eser belki de bu sorunsalın ortaya çıkmasına neden olmuştur. Mecazen miyop bakış açısıyla oryantalist etkilerle yapılmış birçok eser belki de bu hatanın doğmasına sebep olarak gösterilebilir. Tarihten günümüze çeşitli sanat dallarında betimlenmiş Türk imgesi ile seyyah ve elçilerin verdiği bilgiler doğrultusunda karakteristik bir Türk imajından söz edilebilir. Özellikle Avrupa'da yapılmış gravürlerde görülen oryantalist etkilerle yapılmış padişah tasvirleri de bu anlamda yol göstericidir. Avrupalı elçilerin Osmanlı kıyafetlerini kendi ülkelerinde tanıtmak için Kıyafet albümleri hazırlatmaya başlamışlardır. XVIII. yüzyılda ise kıyafet albümleri devam etmekle birlikte batı etkisi artmıştır.

Anahtar Kelimeler: Türk, İmge, Seyyah, Fizyolojik, Giyim-Kuşam

\section{Abstract}

It is possible to encounter artworks on Turkish image in many parts of Europe. Witnessed in various artworks from paintings to sculpture, such portrayals can be seen in several types. In this study, the effects of Turkish image in Europe especially between XVI and XVIII centuries is evaluated. It is aimed to create coherence on the subject through the information about sultans given by travelers based 
on sultan portraits in engravings. In addition, it is aimed to find an answer to the question of what the Turkish image is in European art by examining the facial anatomies, hair and beard styles and outfits of the figures. Mystic and rich culture of the East influenced the West but each artwork produced without seeing and feeling the essence of local culture of East might probably cause this problem to emerge. Metaphorically it can be argued that various artworks produced by orientalist effects with a myopic sight is the reason led to birth of this mistake. It can be discussed about a characteristic Turkish image, based on the information derived from travelers and ambassadors and, Turkish image depicted in various art branches from past to present. European envoys began to have apparel albums prepared to introduce Ottoman clothing in their countries. Although apparel albums were continued to be prepared in the XVIII century, the influence of the West was increased.

Keywords: Turkish, Image, Pilgrim, Physiological, Clothes-Apparel

\section{Giriş}

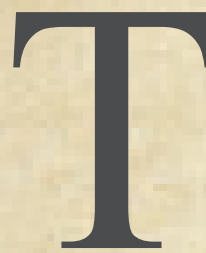

ürklerin tarih öncesi çağlardan itibaren tarihe yön vermiş, geniş coğrafyalara siyasi, askeri ve kültürel özelliklerini taşımıştır. Asya kıtasında Türkistan topraklarından başlayan bu serüven Küçük Asya denilen Anadolu topraklarından geçerek Avrupa'da varlığını uzun süre sürdürmüştür. Osmanlı Devleti'nin kurulmasıyla hız kazanan ilerleme sayesinde farklı bölgelerde çeşitli alanlarda Türk izleri görülebilmektedir. Bu izler kültürel ve sanatsal anlamda Osmanlılar tarafından yapıldığı kadar Avrupalılar tarafindan özellikle XVIII. yüzyıldan sonra oryantalist perspektiften ortaya konulan eserlerden oluşmaktadır. Bu yüzyılda Avrupa'da görülen Turquerie modasına kadar Türkler hep korku duyulan bir millet olmuş ve bu anlamda edebi metinlere ve sanat eserlerine de kötü bir şekilde yansıtılmıştır. Avrupa' da "Türkler geliyor" deyimi bu endişe duyulan duyguların dişavurumudur.

Bu çalışmada Türk nedir kavramından yola çıkarak Avrupa'da Türk imgesini oluşmasına neden olan fizyolojik ve giyim kuşam tanımlamaları üzerinde durulmuştur. $\mathrm{Bu}$ anlamda hem seyyahların yazdıkları hem de görsel sanatlarda rastlanan Türk imgesi XVIII. yüzyıla kadar olan süreç içinde değerlendirilmiştir. Avrupalı sanatçıların çizdikleriyle Osmanlı nakkaşlarının padişahları tasvir etme anlayışında göze çarpan belirgin farklılıklar bulunmaktadır.

\section{1. "Türk" Kavramına Dair}

Türk adıyla tarihte kurulan ilk devlet M.S. VI. yüzyılda kurulan Göktürk Kağanlığıdır. Çin kaynaklarında bu devlet için “Tu-cüeh” (Tukyu/Türk) denilmiştir. ${ }^{1}$ Türk adına ilk kez Göktürk dönemine ait kaynaklarda rastlanılmıştır. Köl, Tigin, Bilge Kağan, Bilge Tonyukuk, Ongin ve Köl İç Çor yazıtlarında Türk ismi geçmiştir. Köl Tigin ve Bilge Kağan yazıtlarında "Türük” biçiminde iki heceli, Bilge Tonyukuk, Ongin, ve Köl İç Çor yazıtlarında ise "Türk" şeklinde tek heceli olarak yazılmıştır. ${ }^{2}$ Türk kelimesinin ilk defa M.Ö. 1328 yıllarına doğru bir Çin vekaayînâmesinde de geçtiği söylenmiştir. ${ }^{3}$ Muhtaran Orazbay, Türk adının ilk çıkışını çok eski "Tele" kavmine dayandırmaktadır. Tele'nin de aynı zamanda "Töre" olması veya "Töreik"e son ek eklenerek Türk

1 Mehmet Öz, “Tarihi Perspektiften Türk Kimliği Üzerine Bazı Düşünceler.” Hacettepe Üniversitesi Türkiyat Araştırmaları (HÜTAD),8(2008), 221.

2 İlhami Durmuş, “Türk Adının Ortaya Çıkışı, Anlamı ve Yayılışı.” Akademik Bakış, 10(20) (2017), 38-39.

3 Yılmaz Öztuna, Cumhuriyet Dönemi Öncesinde Türkler (İstanbul: Babıali Kültür Yayıncılığ1, 2006 ), 29. 
kelimesinin ortaya çıkması ihtimalinin çok olduğunu söylemiştir. ${ }^{4}$ Milli kaynaklarda "törü-mek/ türe-mek" fiiliyle bağlantılı olduğu açıklanmıştır. Fiilin kökü olan "törü" kelimesinden Türk adı ortaya çıkmış, gelişerek "Törük=Türük=Türk" şekline dönüşmüştür. Kelimenin anlamsal karş1lı̆ "türetilmiş, türeyük, yaratılmış, yaratık, doğmuş, insan" olarak ifade edilmiştir. Bu sözün "güç, güçlü, kuvvet, kuvvetli" anlamlarına geldiği de belirtilmiştir. Taşağıl konuyla ilgili, 542 yılında tarih sahnesine çıkan ve 552 yılında da bağımsızlığını ilan eden Göktürk (Kök Türk) devletiyle "Türk" adının resmi bir kimlik kazandığını, kurulan bu devletin ilk adının aslında Gök (Kök)Türk olmadığını, "Türk” olduğunu bazen iki heceli “Türük” şeklinde yazıldığını, XIX. yüzyılda bazı Türkologların teklifiyle akademi dünyasında Göktürk adıyla kabul görüp yaygınlaştığını söylemiştir. Daha sonra kurulacak olan Selçuklu başta olmak üzere diğer bütün İslam devletleri farklı isimle anılmış olsa da kimlik özelliklerini korumuştur. Osmanlı İmparatorluğu üç kıtaya yayıldığında batılılar tarafından Türk Devleti olarak adlandırılmıştır. ${ }^{6}$

Osmanlı topraklarında yaşayan özellikle tüm halklar Avrupa topraklarında Türk adıyla anılmıştır. ${ }^{7}$ XVII. yüzyılda İtalya'da ve diğer Avrupa ülkelerinde "Türk" adı, Müslümanları tanımlamak için kullanılmıştır. Müslüman olan bütün toplumları ifade ettiği gibi ele geçirilen köleler resmi kayıtlara bu sıfatla yazılmıştır. Ele geçirilen esirler arasında Osmanlı tebaasından Hıristiyan ve Yahudiler de "Türk" ismi altında değerlendirilmiştir.

\section{Orta Asya'dan Anadolu Selçuklu Devleti'ne Türk İmgesi Üzerine}

Türk ismine karşılık hem doğu da hem de batıda akla gelen betimleme sanat alanında da çeşitlilik göstermiştir. Göktürk Devletinden başlamak üzere Osmanlı Devletine kadar Türk imgesinin karşıllığı hakkında hem yazılı hem de görsel kaynaklar bize önemli bilgiler sunmaktadır.

I. Göktürk devletinin en büyük hükümdarı olarak kabul gören $\mathrm{Mu}$ Kan hakkında Çin kaynaklarında, yüzünün renginin kızıl ve genişliğinin $30 \mathrm{~cm}$. kadar, gözlerinin donuk ve cam gibi, askeri mücadelesi, savaş vb. işlerde haşin yapıda ve ayrıca zeki, bilgili karakterde olduğu belirtilmiştir. ${ }^{9}$ VI. yüzyılda Mu Kan mavi gözlü ve uzun, kırmızı yüzlü bir Eurepeoid olarak tasvir edilmiştir. ${ }^{10}$

Göktürk devletinde insan tasvirli heykellerin anma törenleri için kurulan tapınakların vazgeçilmez bir unsuru olduğu, bunların ise insan tasvirli dikilitaş ve heykelleri; "geyikli taşlar", Taştık kültürü taş anıtları ve Göktürk balbalları olarak üç gruba ayrıldığı ifade edilmiştir. ${ }^{11}$ Göktürk

4 Muhtaran Orazbay, "Çin Kaynaklarına Göre Esli Türk Kitabeleri," X. Vakıf Haftası Kitabı içinde, haz. İbrahim Ateş, Sadi Bayram, ve Mehmet Narince, (Ankara: Vakıflar Genel Müdürlüğü Yayınları, 1993), 68.

5 Durmuş, Türk Adının Ortaya Çıkışı, 45.

6 Ahmet Taşağıl, Kök Tengri’nin Çocukları, (İstanbul: Bilge Kültür Sanat, 2015), 43-44.

7 Silvio Marchetti, “Avrupalıların Gözüyle Türkler:Mitos ve Yanlış Anlaşılma,” Dünyada Türk Imgesi içinde, haz. Özlem Kumrular, (İstanbul: Kitap Yayınevi, 2005), 9.

8 Mikail Acıpınar, (2010). “XVII. Yüzyılın İlk Yarısında Toskana Grandukalığında Türk Esirler.”Tarih Incelemeleri Dergisi, XXV/1(2010), 19.

9 Ahmet Taşağıl, Bilge Kağan’ın Vasiyeti. (İstanbul: Turan Yayıncılık, 1996), 8.

10 Emel Esin, İslamiyetten Önceki Türk Kültür Tarihi ve İslama Giriş, (İstanbul: Edebiyat Fakültesí Matbaası, 1978), 106.

11 Lale Avşar İskenderzade, “Göktürk Dönemi İnsan Figürlü Taş Anttları.” Selçuk Üniversitesi Sosyal Bilimler Enstitüsü Dergisi 24(2010), 256. 
heykellerinde ölen kişinin hatırasını ebedileştirmek amacıyla ölen kişinin kendisi canlandırılmıştır. ${ }^{12}$ Genel itibariyle erkek heykeller, saçları merkezden iki yana ayrılmış, yanlara doğru taranmış, arkadan örülmüştür, bıyıklı ve halka küpelidir. Üzerinde "V" yaka gömleği ve kaftanı bulunmaktadır. Rus bilim insanı L. A. Yevtühova incelediği 92 Göktürk dönemi erkek heykelinde farklı bıyık tipleriyle karşılaşmıştır ve bunu gerçeği yansıtmak çabasının karşılığı olarak yorumlamıştır. ${ }^{13}$

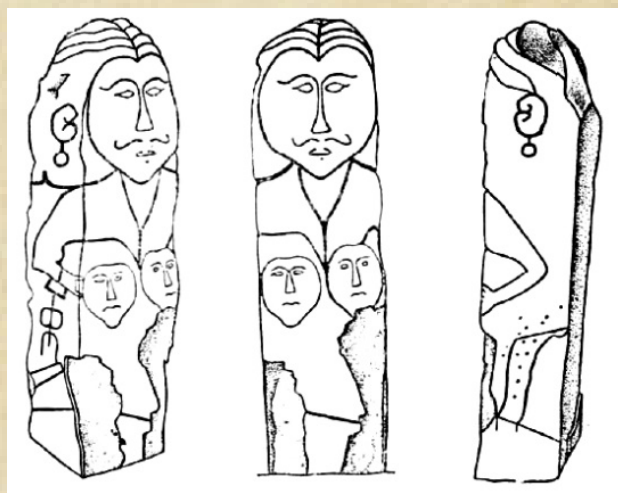

Fotoğraf 1: Göktürk dönemi elinde düşman askerlerinin kesilmiş kafalarını tutan savaşçı heykeli, Ak-Tal-Bacı, Henderge Irmağ 1 , Tuva ${ }^{14}$

Moğolistan'ın başkenti Ulan Bator'un batısında bulunan Mayhan Uul Kurganı VII. yüzyılda Türklerin yaşam kültürü hakkında bilgiler ortaya koymuştur. Bir Göktürk kağanına ait olduğu düşünülen kurganın mezar odasında boyalarla renklendirilmiş insan heykelcikleri ile duvar resimlerine rastlanılmıştır. Duvar resimlerinde yüzleri hüzünlü olarak betimlenen insanların arasında bir de kadın figürü çizilmiştir ve elinde mendile benzer bir bez parçası ile ağlar biçimde tasvir edilmiştir. Duvar resimlerinin başka bir kültüre ait herhangi bir detay olmaması nedeniyle Türk kökenli bir ressam tarafından çizildiği düşünülmüştür. ${ }^{15}$ Burada bulunan heykelciklerden bir tanesinde siyah saçları, bıyığı ve sakalı bulunan keskin bakışlı bir savaşçı tasviri görülmektedir. Gözleri siyah renkte büyük ve çekik betimlendiği kadar iri bir buruna sahiptir. Başlığı kulaklarını örtmektedir ve zırhında ise yaka bölümünde çeşitli palmet motifleri yer almaktadır (Bkz. Fotoğraf 2). Bulunan duvar resimlerinde görülen insan figürlerinin birinde atını yularından tutmuş bir erkek görülmektedir ve uzun saçlıdır. Oval yüz yapısındadır, siyah renkte saçları ve kaşı ile çekik gözleri, iri burnu vardır. Üst bölümünde kırmızı renkte yakası açık, belden kemerli kaftan tarzı bir kıyafet betimlenmiştir. Ayrıca büyük olasılıkla pantolon giydiği söylenebilir (Bkz. Fotoğraf 3). Göktürkler elbiselerine ton (don) veya kedüm/kedgü adını vermiş olup bunlar hem iç hem de dış elbiseler şeklinde ikiye ayrılmıştır. Çeşitli tasvirlerden edinilen bilgiler çerçevesinde giyim ve kuşamlarının günümüz kıyafetlerine oldukça yakın olduğu bildirilmiştir. ${ }^{16}$ Özellikle bir Türk kıyafetinde başta börk, vücutta kaftan, bunun altında çeşitli isimlerle anılan hırka, ceket ve gömlek bulunmaktadır. Şalvar (pantolon), çizme veya ayakkabı ile kıyafet tamamlanmıştır. ${ }^{17}$

\footnotetext{
12 Avşar İskenderzade, Göktürk Dönemi İnsan, 259.

13 Avşar İskenderzade, Göktürk Dönemi İnsan, 262.

14 Avşar İskenderzade, Göktürk Dönemi İnsan, 269.

15 Sartkojauli Karcaubay ve Cantekin Karcaubay, “Göktürk'ün Toprak Halkı.” Atlas Dergisi 238(1 Ocak 2013), 71.

16 Hacer Nurgül Begiç, “Giyim-Kuşam Kültüründe Keçe Sanatına Tarihsel Bir Bakış”, Selçuk Üniversitesi Türkiyat Araştırmaları Dergisi, 40 (2016), 291.

17 Mehmet Altay Köymen, “Alp Arslan Zamanı Türk Giyim Kuşamı.” Selçuklu Araştırmaları Dergisi,
} 


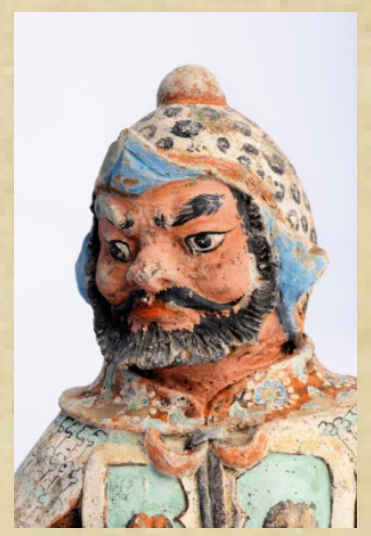

Fotoğraf 2: Göktürk erkeği renkli heykelciği ${ }^{18}$

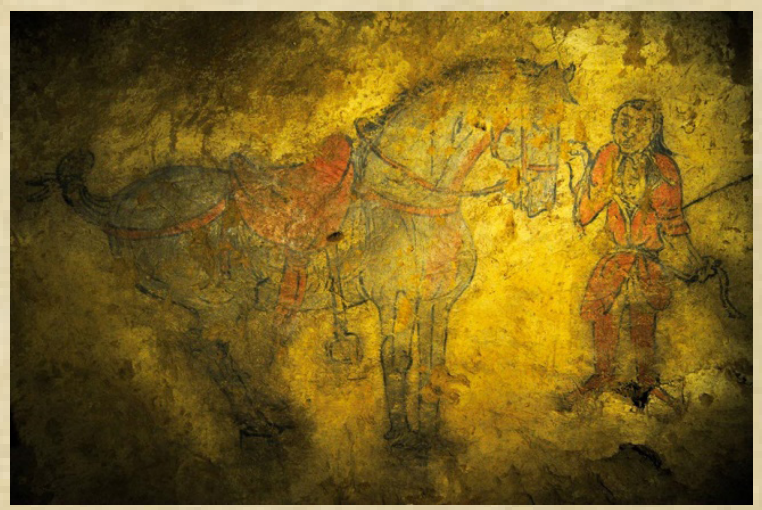

Fotoğraf 3: Mayhan Uul Kurganı duvar resminde görülen Göktürk erkeği betimlemesi ${ }^{19}$

Çin kaynaklarında Li Ling adında M.Ö. 99'da Kansu'da Yü-men-kuan dolaylarında Chiuc'üan'ın kuzeyinde bir yerde Hsiung-nu (Hun) devletine karşı savaşan Çinli bir general yaşadığı yazılmıştır. Li Ling, Hunlar tarafından esir alınmıştır. H sin T'ang shu kitabındaki bir diğer ayrıntıda (Kırgızlar hakkındaki bölüm) Li Ling'e daha sonra "Yu-hsein Wang" unvanının verildiğini ve kara gözleri olduğu için Kırgızların Li Ling'in erkek torunu olduğu söylenmiştir. ${ }^{20}$ Aslında bu konu bir başka Çin kaynağında farklı anlatılmıştır. VIII. yüzyılda Li Ling, yeşil gözlü ve kızıl saçlı Kırgızlara vali olarak atanmıştır. Kırgızlar, Li Ling’in mahiyetindeki Çinliler ile bu devirde karışarak onlara benzemeye başlamıştır. Kırgızlar, Çinlilere benzeyenleri uğursuz saymışlardır. ${ }^{21}$ Aslen Kırgızlar çoğunlukla Çin kaynaklarında yeşil gözlü ve kızıl saçlı olarak tanıtılmıştır. ${ }^{22}$

Uygur Türklerinin duvar resimleri genellikle Mani ve Buda dinlerinin etkisi altında yapılmıştır. Uygurlar tasvirlerinde özellikle mavi ve kırmızı renkleri tercih etmişlerdir. Duvar resimleri VIII. ve

3(1971), 59.

18 Karcaubay ve Karcaubay, Göktürk'ün Toprak Halkı, 67.

19 Karcaubay ve Karcaubay, Göktürk'ün Toprak Halk1, 63.

20 Özkan İzgi, Çin Elçisi Wang Yen-Te'nin Uygur Seyahatnamesi, (Ankara: Türk Tarih Kurumu, 1989), 51.

21 Esin, İslamiyetten Önceki Türk,51-52.

22 Esin, İslamiyetten Önceki Türk,105. 
IX. yüzyıldan kalma eserlerdir. Heykel sanatında ise Göktürk balbal geleneğinden gelen özellikler görülmektedir. ${ }^{23}$ Uygur mezarlarında ele geçen buluntular bu dönemdeki insan tipleri hakkında bilgi sahibi olmamızı sağlamaktadır. Sanpul Kasabası'nda bulunan mezarlardaki cesetlerin çoğuna renkli yün pantolon giydirilmiş ve bu pantolonun sol bacağına bir insan resmi betimlenmiştir. Pantolona kabartma tekniğinde dokunmuş resimde işlenen insanın kaşları siyah, ağzı kırmızı, gözleri yeşildir. Bu resim Oğuz Kağan destanında anlatılan Oğuz Kağan’ı hatırlatmaktadır. Destanda, Oğuz Kağan'ın yüzü mavi, ağzı ateş gibi kırmızı, gözleri yeşil, saç ve kaşlarının siyah olduğu anlatılmıştır. ${ }^{24}$ Uygur resim sanatı primitif, arkaik ve klasik dönem olarak üç gruba ayrılmıştır. ${ }^{25}$ Klasik dönem olarak adlandırılan üçüncü evrede figürlerde Uygur-Türk tipinin olgun örnekleri yoğun bir şekilde kullanılmıştır. Bu evrede aynı zamanda, anatomik olarak badem göz, küçük ağız, küçük burun, hafif şişkin yanaklar ile "Uygur Tipi” veya "Uygur Insanı" olarak adlandırılan üslup özellikleri görülmekle birlikte Hint ve Çin etkisi iyice azalmıştır. Bu üslup özelliği Anadolu Selçuklu dönemi çini ve minyatür süslemelerinin ana karakterini oluşturmuştur (Bkz. Fotoğraf 4) ${ }^{26}$

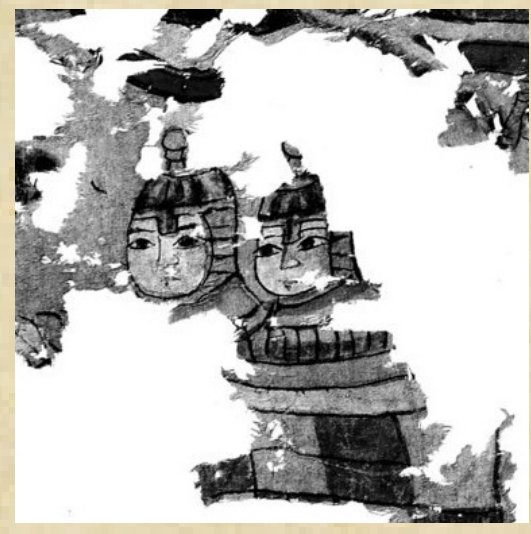

Fotoğraf 4: Klasik dönem Bezeklik duvar resimleri insan figürleri²7

Anadolu Selçuklu sanatında görülen insan figürlerinin açıkça Uygur ve Gaznelilere ait duvar resimlerinde görülenlerle kıyafet ve yüz biçimleri ile sahne açısından benzerlik gösterdiği söylenmiştir. ${ }^{28}$ Uygur giysileri genel anlamda bozkır kültürünün izlerini taşımaktadır. Çizme, börk, eşya asmak için kayış veya kuşaktan yapılma kuşakları bulunmaktadır. ${ }^{29}$ Ancak Maniheizm ve Budizm etkisinde kaldıklarından dolayı fresk ve ipek üzerine boyanmış resimlerde kişilerin beyaz veya kırmızı renkli elbiseleri ve külahlarının bulunduğu belirtilmiştir. Türk toplumları arasında yaygın olarak kullanılan keçe şapka ve külahlara Uygur Dönemi’nde tepecikler eklenmiştir. ${ }^{30}$

23 Saadettin Gömeç, Uygur Türkleri Tarihi ve Kültürü, (Ankara: Atatürk Kültür, Dil ve Tarih Yüksek Kurumu, 1997), 82.

24 Hüseyin Tekinoğlu,Uygurlar, (İstanbul: Kamer Yayınları, 2015), 157-158.

25 Yunus Berkli, "Uygur Resim Sanatının Üslup Özellikleri.” Atatürk Üniversitesi Edebiyat Fakültesi Sosyal Bilimler Dergisi, 10/45 (2010), 157.

26 Berkli, “Uygur Resim Sanatının”, 162.

27 Yunus Berkli, = "Uygur Resim Sanatının”, 162.

28 Tolga Erkan, “Anadolu Selçuklu Sanatındaki İnsan Figürlerinin Uygurların Mağara Resimleri ve Gaznelilerin Duvar Resimleriyle Konu ve Biçim Yönünden Karşılaştırılması.” Turkish Studies, 5/3(2010), 1257.

29 Hacer Nurgül Begiç, Türk Keçecilik Sanatı. (Ankara: Atatürk Kültür Merkezi Başkanlığı, 2017), 28

30 Hacer Nurgül Begiç, Türk Keçecilik Sanatı, 29 
Selçuklu kıyafetleri hakkında Eflaki’nin oldukça aydınlatıcı bilgileri vardır. Eflaki, erkek elbiselerinin başlıca Yemen kumaşından elbise (Burd-i Yemeni), Mısır elbisesi, siyah ince ipek elbise, Misır ve şâs ipeğinden elbise, gaşiye, Bûrî kumaş, Çuha ve Kemha ve Sof'tan (ince dokunmuş yün kumaş) yapıldığından bahsetmiştir. Elbise çeşidi olarak Hulle (belden aşağ 1 ve belden yukarı olmak üzere iki kısımdan ibaret elbise) ile Fereci'yi örnek vermiştir. Fereci, göğsü açık uzun kollu bir cüppe türü olarak tanımlanmıştır. Ayrıca, kabâ, kurt postu, tilki postunun da giyildiğini söylemiştir. Şalvar ve gömleğin de ayrı bir önem teşkil ettiğini, hırka olarak Hint hırkası (Burd-i Hindi) ve geniş kollu hırkaların olduğunu ifade etmiştir. Kürk kullanılarak pahalı elbiselerin yapıldığını, samur kürklü kırmızı sskarlat çuhasının giyildiğini belirtmiştir. Başlık olarak sarıklardan bahsetmiş ve bu başlıkları Şaş-1 Hindi Sarı̆̆ı, yünden yapılmış Mısır Sarığı, lâliş sarık, Şekarâviz sarık olarak birbirinden ayırmıştır. Karakeçe ve beyaz külahtan söz etmiştir. Ayağa ise ayakkabı veya çizme giyildiğini belirtmiştir. ${ }^{31}$ Anadolu Selçuklu Dönemi sanatında görülen hükümdar tipleri genelde bağdaş oturmuş vaziyettedir. Dolgun yüz hatları, örgülü saçları vardır. Zülüfleri önden ve yandan göğsüne kadar inmektedir. Sağ kulağındaki küpe belirgin olarak halka biçimlidir. ${ }^{32}$ Kaftanları sağdan sola doğru kapanmış vaziyette betimlenmiştir. ${ }^{33}$ Göktürklerde ise kaftanlar soldan sağa kapanmış şekilde tasvir edilmiştir. ${ }^{34}$ Kubad Abad çinilerinde görülen insan figürleri ile ilgili Berlin İslam Sanatı Müzesi’nde bulunan minai tekniğinde yapılmış sekiz kollu çini örneğinde yuvarlak yüzleri, badem gözleri, küçük burun ve ağzıyla Türk tipini temsil etmektedir. Bu Uygurlardan beri ortaya çıkan Türk figür tipinin devamı niteliğindedir. ${ }^{35}$

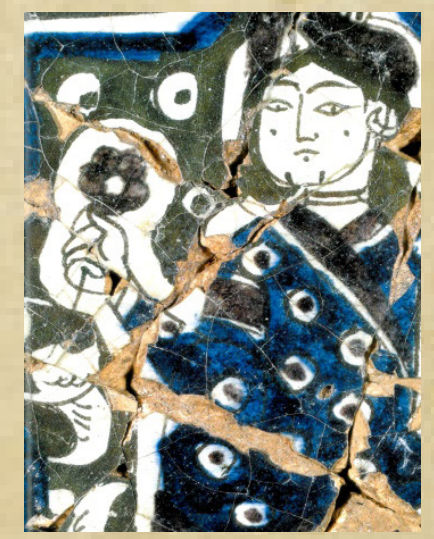

Fotoğraf 5: Kubad Abad çinileri bağdaş kuran figür ${ }^{36}$

\section{Osmanlı Devleti’nde Türk İmgesi ve Giyim Kuşam Kültürü}

Osmanlı devletini ziyarete gelen birçok seyyahın kaleme aldıkları dönem anıları o günün kültürü hakkında detaylıca bilgi vermektedir.

31 Aydın Taneri, Türkiye Selçukluları Kültür Hayatı. (Konya: Akın Basımevi, 1977), 72-73.

32 Özden Süslü, Tasvirlere Göre Anadolu Selçuklu Klyafetleri. (Ankara: Atatürk Kültür Merkez, 2007), 159.

33 Süslü, Tasvirlere Göre Anadolu, 160.

34 Süslü, Tasvirlere Göre Anadolu, 188.

35 Rüçhan Arık, Kubad Abad. (İstanbul: Türkiye İş Bankası, 2000), 33-34.

36 Rüçhan Arık, Kubad Abad, 137. 
Osmanlı resim geleneği içinde konusu öncelikli olarak kıyafetler olmasa da bazı padişah portrelerinde ayrıntılı giyim-kuşam detayları işlenmiştir. XV. yüzyıldan sonra Osmanlı topraklarına ziyarete gelen diplomat, tüccar veya seyyahların yazdıkları hatıratları resimleriyle birlikte basılmıştır. Avrupalı elçilerin Osmanlı kıyafetlerini kendi ülkelerinde tanıtmak için Kıyafet albümleri hazırlatmaya başlamışlardır. XVIII. yüzyılda ise kıyafet albümleri devam etmekle birlikte batı etkisi artmıştır. Bu yüzyıl Osmanlı Devleti adına batılılaşma süreci olduğu için batı ile ilişkilerin arttığı bir dönemdir. XVIII. yüzyılın sonu ve XIX. yüzyılın başında Osmanlı gündelik yaşamına ve kıyafetlerine duyulan önem ve padişah I. Abdülhamid (1774-1789) döneminde başlayan sultanların batıya duydukları ilgiyle birlikte orantılı olarak kıyafet albümlerinin yapılmasına devam edilmiştir. ${ }^{37}$

Rönesans'tan hemen sonra Avrupalı sanatçılar resimlerinde doğu imgeli obje, eşya veya giyim kuşam öğelerini kullanmıştır. ${ }^{38}$ XIX. yüzyılda Türk-Osmanlı imajında bir önceki dönemlere göre bazı değişsiklikler görülmüştür. Daha önceki dönemlerde Batılı sanatçılar Osmanlı dünyasını belirli bazı yönlerini ön plana çıkartmıştır. Ancak XIX. yüzyılda kültürün özüne inmeye çalışmışlardır. Osmanlı'nın gelenek ve görenekleri ile gündelik yaşamını, etnik yapısını, kıyafetlerini ve mimarisini belgeleyen eserler ortaya koymuşlardır. ${ }^{39}$

XVI. yüzyılda Osmanlı erkeklerinin giyim kuşamı hakkında ayrıntılı bilgi veren seyyah F. Moryson hatıratında, erkeklerin saçlarını tıraş ettiğini, tepede bir tutam saç bıraktıklarını, bıyık ve sakal uzattıklarını söylemiştir. Tıraşlı başlarını kırmızı bir takke ile örttüklerini bunun üzerine de yuvarlak küre biçiminde 12-20 elle (uzunluğu değişen bir ölçü, bez ölçüsü, yaklaşık 1¹/4 yarda, yarda:0.914m.) uzunluğunda ince beyaz ketenden bir bez sardıklarını buna ise Türkçe tülbent veya tsalma (salma) adının verildiğini ifade etmiştir. Baş giysilerinin içi boş olduğu için kafalarının hava aldığını, küçük çemberlerle desteklediği için başı serin tuttuğunu, kalın olduğundan güneşin geçmediğini, ince keten bezinden yapılmış olmasından dolayı da Avrupalıların kullandıklarından hafif olduğunu anlatmıştır. Rütbeleri, sarıkları üzerindeki işaretlerden bellidir, demiştir. ${ }^{40}$

Antoine Galland ise 1672 yılında İstanbul'da gördükleri üzerine yazdığı hatıratlarında dönemin padişahı Sultan IV. Mehmed hakkında da bazı açıklamalar vardır. 9 Nisan 1672 yılındaki padişahın Edirne'de Sultan Selim Cami'nde kılacak olduğu bayram namazıyla ilgili anlattığı hatıratında, Sultan IV. Mehmed'in esmer tenli olduğunu belirtmiştir hatta onun İstanbul doğumlu olmasına rağmen bu esmer ten için Anadolu Türklerinin rengidir, demiştir. Padişahın çehresinin dolgunluğunu söylemiştir. Alnının üzerinde duran sarığında oldukça irilikte firuze ile bağlanmış tüylerin bulunduğunu, ayrıca her iki tarafta birer tutam balıkçıl kuşu tüyünün varlığından bahsetmiştir. ${ }^{41} 27$ Haziran 1673 yılında kaleme aldığı hatıratında padişahın kullandığı sarığın sıradan ve hemen hemen Türklerin taşımak zorunda olduğu bir sarık tipinde olduğundan bahsetmekle birlikte hiçbir Türk sarığında görülmeyen özelliğin siyah, beyaz ve gümüş renginde düzenlenmiş özel bir görünüm arz eden balıkçıl kuşu tüyünden yapılmış sorgucunun olduğunu

37 Pelin Şahin Tekinalp, "Geleneğin Devamı:Bahriyeli Ressam Hüsnü Tengüz’ün Kıyafet Albümü.” Hacettepe Üniversitesi Edebiyat Fakültesi Dergisi, 31/1 (2014), 212.

38 Seyfi Başkan, Sanat ve Tarih. (Ankara: Çardaş Yayıncılık, 2000), 38.

39 Seyfi Başkan, Sanat ve Tarih, 40-41.

40 Tülay Reyhanlı, İngiliz Gezginlerine Göre XVI. Yüzyılda İstanbul〉da Hayat. (Ankara: Kültür ve Turizm Bakanlığı Yayınları, 1983), 70.

41 Antoine Galland, A., İstanbulıa Ait Günlük Hatıralar(1672-1673). haz. Charles Schefer ve çev. Nahid Sırrı Örik (Ankara: Türk Tarih Kurumu, 1998a) I:95. 
söylemiştir. ${ }^{42}$ Tüylü sorguç geleneğinin Türkistan coğrafyasından Şamanist inanışlar çerçevesinde gelişerek Anadolu'ya taşındığı ifade edilebilir. Türklerin Anadolu'ya gelirken getirdikleri en çok kalıcı olan takı başlı̆ga takılan tüyler ve sorguçlardır. ${ }^{43}$

Kaşgarlı Mahmud'un Divanı'nda börk ve börkçülük mesleğinden oldukça bahsetmiştir. Yine aynı eserinde börkçü dükkânı ve börkün önemine dair "Acemsiz Türk, başslz börk olmaz" diye bir atasözünü belirtmiştir. Ancak sarığın börkün etrafına sarıldığına dair Kaşgarlı'nın eserinde net bir ifade kullanılmamıştır ama buna rağmen sarık kullanıldığına dair bazı bilgiler mevcuttur. Örneğin, aynı Divanı'nda "ol suvluk sarladı" = O (adam) sarık sardı, ifadesi geçmiştir. ${ }^{44}$ Sarık, Avrupa'da Türk İmgesi’nin vazgeçilmez bir sembolüdür.

Sarık, üzerine veya çevresine sarılan destarın arasından veya genellikle tepe kısmından üzerine sarılan takkenin büyük bir kısmının görüldüğü başlıklara verilen isimdir. Kavuk ise, beyaz bir tülbendin çoğunlukla altındaki yüksek başlığı tamamen örtecek şekilde sarılarak veya rapt edilerek kapattığı başlık türüne denilir. ${ }^{45}$ Ancak, Halit Çal, kavukta üzerine sarılan başlığın büyük ölçüde görüldüğünü ifade etmiştir. ${ }^{46} \mathrm{Ayr}$ rca, Osmanlı toplumunda fes kullanılmadan önce giyilen kavukların sarıklı olmalarından dolayı sarıklı kavuk ile aynı isimle tanımlandığını anlatarak, XV-XVII. yüzyılda giyilen kavuklarda üzerine sarık sarılan başlık ya hiç görünmez ya da sadece tepesinin göründüğünü, XVIII.-XIX. yüzyllda ise kavuklarda başlık bölümünün büyük ölçüde göründüğünü söylemiştir. Sarıkların sarılış biçimlerine göre burma, civan kaşı, kâtibi, dardağan, perişani ve silme gibi tiplere ayrıldığını ifade etmiştir. ${ }^{47}$ Kavuklar ise yusufi, kallavi, horosanî, kâtibi, mücevveze, selimî, kalensüve, perişanî, kubadî, azamî, örfî, kafesi gibi türlere ayr̃̄ılmıştır. ${ }^{48}$

Sarık, gayrimüslimler karşısında Müslümanların ayırıcı bir özelliği olarak görülmüştür ve bu nedenle İslam kültürünün bir sembolüdür. ${ }^{49}$ Öyle ki İstanbul'un fethinden önce Bizanslı Grandük Notaras, "Kostantinopolis'te kardinal şapkası görmektense Türk sarığını görmeyi tercih ederim" diyerek sarığın Türk-İslam sembolü olduğunu vurgulamıştır. ${ }^{50}$ Türklerin de sarığı İslamiyet'i seçtikten sonra Araplardan aldığı söylenmiştir. Öyle ki, Selçuklu hükümdarı Tuğrul Bey 1065 yılında Bağdat'ta Halifenin kızıyla evlenerek bir anlamda Abbasi Halifesinin himayesine girmekle birlikte bazı yetkilerini de almıştır. Böylece Araplar ile Türkler arasında kültürel bir alışverişin başladığı da bu anlamda görülmüştür. Örneğin, Tuğrul Bey 1038 yılında Nişabur’a geldiği zaman ilk kez başına sarık sarmıştır. Türkler yeni aldıkları bu giysiye hemen kendi hoşlarına gidecek

42 Antoine Galland, A., İstanbulıa Ait Günlük Hatıralar(1672-1673). haz. Charles Schefer ve çev. Nahid Sırrı Örik (Ankara: Türk Tarih Kurumu, 1998b) II:75.

43 Sabahattin Türkoğlu, Tarih Boyunca Anadolu'da Giyim Kuşam. (İstanbul: Atılım Kağıt Ürünleri ve Basım, 2002), I:148.

44 Köymen, "Alp Arslan Zamanı", 62.

45 Ökkeş Hakan Çetin, Ö. "Onyedinci Yüzyıla Ait Kıyafet Albümlerinde Osmanlı Erkek Giyim-Kuşamı.” The Journal Of Academic Social Science 53(2016), 262.

46 Halit Çal, “İstanbul Eyüp’teki Erkek Mezar Taşlarındaki Başlıklar.” Tarihi, Kültürü ve Sanatıyla III. Eyüp Sultan Sempozyumu, (İstanbul:2000), 210.

47 Çal, İstanbul Eyüp’teki Erkek Mezar, 209.

48 Abdülaziz Bey, Osmanl Adet, Merasim ve Tabirleri. haz. Kasım Arısan ve Duygu Günay Arısan (İstanbul: Tarih Vakfi, 1995), 224.

49 Walther Björkman, "Sarık." İslam Ansiklopedisi, c.X (İstanbul: Milli Eğitim Basımevi, 1967), 222.

50 Ziya Kazıcı, “İslam Devletlerinin Zimmi Tebeaya Bakışı (Osmanlı Örneği).” Kur'an-ı Kerim'de Ehl-i Kitab Tartışmalı İlmi Toplantı, (İstanbul, 2007), 322. 
şekilde kendi karakterlerine uygun biçim vererek yeni bir sarık modeli yaratmışlardır ve buna "Türk Sarı̆̆ı" adı verilmiştir. Mısır' da Memlükler tarafından giyilen bu sarık tipi, üstten iki tarafa doğru çıkıntılıdır ve genelde törenlerde giyilmiştir. ${ }^{51}$ Anadolu Selçuklu Devleti döneminde sarı̆̆ din ve devlet adamları kullanmıştır. Osmanlılarda ilk kez resmi toplantı ve törenlerde sarık veya kavuk giyme geleneğini başlatan Orhan Bey'dir. "Dal külah” veya "dal börk” (sarıksız börk) ile törenlere katılan beylere "burma sarığın nerede?" diye uyarıda bulunulduğu anlatılmıştır. ${ }^{52}$

Sarığın renkleri toplum bireylerinin kimlikleri konusunda bilgiler vermiştir. ${ }^{53}$ Moryson, XVI. yüzyılda Osmanlı'da halkın da tülbentler taktığını ancak renklerinin sade ve saf beyaz olduğunu, Rum ve diğer Hristiyan ile yabancıların küçük bir takkenin kenarına sarılmış genellikle mavi-beyaz çizgili keten "shasses" adı verilen başlıklar giydiklerini söylemiştir. ${ }^{54}$ Özellikle Kanuni Sultan Süleyman zamanında giyimleri tertip etmek amacıyla çıkartılan kanunda beyaz renk Müslümanlara tahsis edilmekle birlikte Müslüman olmayanların kırmızı, sarı ve siyah renk taşımaları uygun görülmüştür. Önceleri Hristiyanlar gök renk, Museviler sarı renk takke giyerken 1592 yılında Hristiyanlar siyah, Museviler kırmızı giymeye başlamıştır. Bir süre sonra da Musevi takkeleri mor renk olmuştur. ${ }^{55} 1683$ yılına doğru Sultan IV. Murad zamanında sadece İstanbul Türkleri beyaz sarık sarmıştır. Mısır Arapları çeşitli renklerde sarık, mağripler de altın işlemeli beyaz sarık taşımıştır. Ayrıca bu dönemde Filistin'de Yahudi ve Hristiyanlar mavi sarık kullanmıştır. Hatta bu dönem Hristiyanlarının sarıklarında mavi bir şerit taşıdıkları bu açıdan cizye tahsildarlarının kendilerini tanımalarının kolaylaştığı ifade edilmiştir. ${ }^{56}$ Osmanlı Devleti'nde ulema, padişahlar, vezirler ve diğer devlet memurları farklı şekillerde daima beyaz tülbent sarık kullanmıştır. ${ }^{57}$

Osmanlı padişahlarının günlük yaşamda altta şalvar, üstte gömlek veya iç entarisi, üzerine kısa kaftan (ceket tarzında) veya uzun kaftan giymiştir. İç entarileri resmi günlerde, dirsekten bileğe kadar düğmelidir ve bileğe göre ayarlanabilen kolu bulunmaktadır. Bunun üzerine kemha, seraser, kadife, çatma gibi ağır ipliklerden özenle hazırlanmış kısa kollu kaftan ve en üstte içi kürklü, mücevher düğmeli, yere kadar uzun etekli ve kollu üst elbiseleri vardır. Bu görkemli üst giyime kapaniçe/kapaniça adı verilmiştir. ${ }^{58} \mathrm{Bu}$ konudaki bir başka kaynakta Osmanlı erkek giyimi üç, dört kat üst üste giyilen kıyafet parçalarından en üste giyilen dışında iç tarafta bulunanlar iç kaftanı, entari, dolama ve mintan gibi isimlerle tanımlanmıştır. XVII. yüzyılda İstanbul'da yaşamış olan seyyah Thevenot, doliman veya dolama adı verilen giysiyle ilgili olarak, erkeklerin hem önden hem de arkadan kapalı bir don giydiğini, gömleklerinin uzun olduğunu ve bu nedenle donun üstünden aşağıya düştüğünü, bu gömleğin üzerinde ise topuklara kadar inen dar kol ağızlı, elin sırtını kaplayan yuvarlak bir kısmı bulunan doliman adı verilen bir entariden bahsetmiștir. ${ }^{59}$

51 Türkoğlu, Tarih Boyunca Anadolu'da, 137.

52 Türkoğlu, Tarih Boyunca Anadolu'da, 158.

53 Türkoğlu, Tarih Boyunca Anadolu'da, 158

54 Reyhanlı, İngiliz Gezginlerine Göre, 71.

55 Abdülaziz Bey, Osmanlı Adet, Merasim, 225.

56 Björkman, "Sarık", 223.

57 Reşat Ekrem Koçu, Türk Giyim Kuşam ve Süslenme. (Ankara: Sümerbank Kültür Yayınları, 1967$), 202$.

58 Hülya Tezcan, "Topkapı Saray Müzesi Giyim Kuşam Koleksiyonu Saray Kıyafetleri.” Osmanlı Ansiklopedisi “Kültür ve Sanat” içinde, haz. Eren Güler, c. XI (Ankara: Yeni Türkiye Yayınları, 1999), 51.

59 Emine Koca, Fatma Koç. “Kıyafetnameler ve Ralamb’ın Kıyafet Albümün'deki 17. Yüzyıl Osmanlı Toplumu Giysi Özelliklerinin İncelenmesi,” Turkish Studies, 9(11) (2014), 384 
Bu kıyafetlerin bazı bölümlerinin farklılık içerdiğine dair XVII. yüzyılda Ralamb’ın albümünde bulunan erkek figürlerindeki şalvar, göynek, içentari, dolama ve kaftandan oluşan Türk ve diğer erkek giysilerinin düz silüet formunda olduğu, dolama ve kaftanların boyun çevresini saran yaka biçimlerinin benzerlik göstermediği sadece kaftanların kol biçimlerinin farklılık içerdiği ifade edilmiştir. $^{60}$

XVIII. yüzyıl başlarında da Osmanlı elçilerinin giydiği kıyafetlere bakıldığında sarık kullanımı devam etmiştir. Sırtlarındaki iç elbiseleri çeşitli renklerdedir. Bunun üstüne giydikleri kaftanın rengi ise genelde kırmızı veya mavidir. Bazılarında kürk bulunmaktadır. Kuşaklarında hazineden emanet olarak verilen hançer taşıdıkları ifade edilmiştir. XIX. yüzyılda ise fes kabul edildiğinden elçiler fes ve siyah çuhadan elbise giymiştir. Forma olarak rütbelerine göre tel ile işlemeler vardır ve bunların üzerinde de kazandıkları nişanları taşımışlardır. ${ }^{61}$

Türk korkusunun tasavvuruna dair somut çizimler sarığın da konu olduğu şeytani kompozit betimlemelerdir. XIV. ve XV. yüzyıllarda bazı Alman hacıları Türkiye hakkında bilgiler yazmıştır. O dönemde Avrupa' da bir Türk korkusu yaşandığı gerçektir. Türkler bazen doğaüstü bir varlık olarak görülmüş bazen de kan içici, barbar olarak tanımlanmıştır. Hatta basılan bazı kitaplarda Hristiyan düşüncesinin kötü tezahürü olarak Türkler boynuzlu, kuyruklu bir şeytan olarak tasvir edilmiştir. ${ }^{62}$ XVI. yüzyıldan Sanayi Devrimi’nin gerçekleştiği XVIII. yüzyılın sonlarına kadar Avrupalıların yarattığı Osmanlı imgesi “korkulan barbar, düşman ve saygı duyulan devlet” arasında aşağılama ve yüceltme ikilemine dayalı değişkenlik göstermiştir. Osmanlı İmparatorluğu'nun özellikle XVIII. yüzyılda gücünü yitirmesiyle birlikte imgesinin korkutucu özeliği Avrupa' da kaybolmuştur. ${ }^{63}$
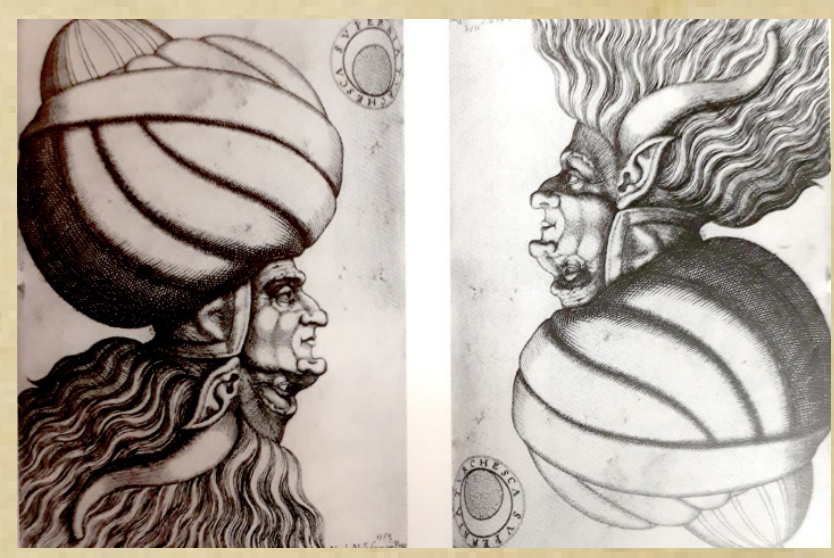

Fotoğraf 6: Nicolò Nelli’nin 1571 yılında çizdiği Osmanlı’y1 şeytan gibi tasvir eden gravür çizimi $^{64}$

60 Emine Koca, Fatma Koç. “Kıyafetnameler ve Ralamb’ın”, 392

61 Faik Reşit Unat, Osmanlı Sefirleri ve Sefaretnameleri. haz. Bekir Sitkı Baykal (Ankara: Türk Tarih Kurumu, 1968), 237.

62 Şafak Tunç, Şehristan Seyyahların Hayal Şehri İstanbul. (İstanbul: İstanbul Ticaret Odası, 2010), 41-44.

63 Aytül Papila, (2008). "Osmanlı İmparatorluğu nun Batılılaşma Döneminde Resim Sanatının Ortaya Çıkışı ve Osmanlı Kimliğinin Resimsel Anlatımı." Gazi Üniversitesi Sanat ve Tasarım Dergisi, I/1 (2008), 119.

64 Julian Raby, "La Serenissime et la Sublime Porte: les arts dans l'art diplomatique." haz. Yves Guena, Venise et l'Orient 828-1797(Paris: Editions Gallimard, 2006), 91. 
Osmanlı padişahları taç kullanır mıydı? hipotezine cevap aranacak olursa bununla ilgili bulgular için Orta Asya kültürüne kadar gitmek gerekebilir ancak elde edilen sonuçlar elbette Osmanlı padişahlarının taç kullandıklarına dair gerçekçi bir bilgi veremez.

Taç, hükümdarların başına giydikleri değerli mücevherlerle bezenmiş taht ile birlikte hükümdarlık simgesidir. ${ }^{65}$ Özden Süslü’nün, Atasoy'dan aktardığı üzere taç şekilleri ve geleneği Orta Asya Hun devri kurganlarına kadar dayandırılmıştır. ${ }^{66}$ TİKA'nın desteğiyle 1997 yılında başlatılan "Moğolistan'daki Türk Anıtları Projesi” kapsamında Türk arkeolog ve tarihçiler 2001 yılındaki Bilge Kağan Külliyesi araştırmalarında sunak civarında altın, gümüş, bakır, bronz ve değerli taşlardan oluşan yaklaşık 4500 parça eser bulmuştur. Bu eserler arasında Bilge Kağan'ın anka kuşu motifiyle süslü tacı da ele geçmiştir. ${ }^{67}$ (Bkz. Fotoğraf 7). Özden Süslü, taç şekillerini tek taşlılar, diadem, dilimli taç olmak üzere üç gruba ayırmıştır. Dilimli taçlarda; tek dilimli, iki dilimli, üç ve daha fazla dilimli olarak kendi içinde tiplere ayrılmıştır. Ancak, Göktürklerde Altay’da bulunan sosyal hayatı tasvir eden kompozisyonda bir erkek tasvirinde görülen üç ve daha fazla dilimli (terekli) taç haricinde, diğer türler kadınlarda kullanılmıştır. Bu taç şeklinin küçük dilimler şeklinde oluşan bir çeşidi taş kalıp üzerinde bulunmuştur. ${ }^{68}$ İki adet $10 x 6 \mathrm{~cm}$. boyutlarında taş kalıptan oluşan eser bulunmaktadır. XII. yüzyıla tarihlendirilen eserin Musul civarlarından geldiği belirtilmiştir. ${ }^{69}$ (Bkz. Fotoğraf 8).

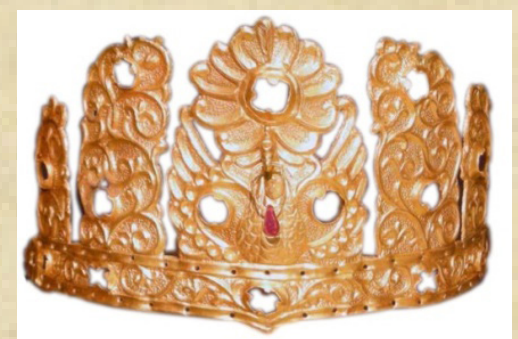

Fotoğraf 7: Bilge Kağan’a ait olduğu düşünülen altın taç70

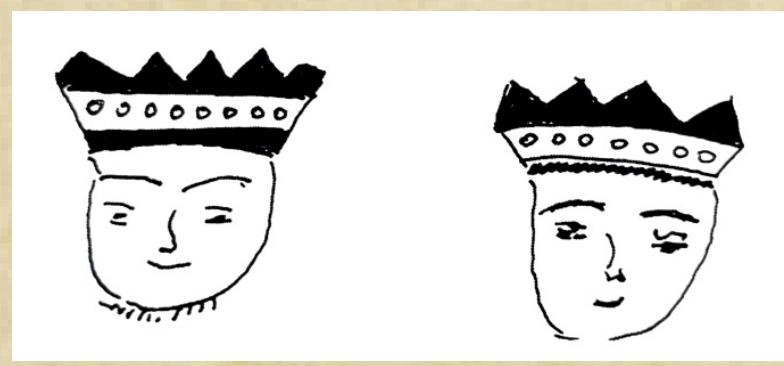

Fotoğraf 8: Türk İslam Eserleri Müzesi'nde 1915 envanter numarasıyla bulunan taş kalıplarda görülen taç giymiş figürler ${ }^{71}$

65 Koçu, Türk Giyim Kuşam, 220.

66 Süslü, Tasvirlere Göre Anadolu, 140.

67 İlhan Özkeçeci, “Orhun Abidelerinin Estetik ve Muhtevasının Önemi.” haz. Ülkü Çelik Şavk, III. Uluslararası Türkiyat Araştırmaları Sempozyumu, (Ankara, 2011), II:655.

68 Süslü, Tasvirlere Göre Anadolu, 141.

69 Süslü, Tasvirlere Göre Anadolu, 106.

70 Özkeçeci, “Orhun Abidelerinin Estetik”, 656.

71 Süslü, Tasvirlere Göre Anadolu, 404. 
Taç, Arapçada ve Eski Farsçada "tag" kelimesinin karş1lığıdır ve İran kökenli yabancı bir sözcüktür. Eski İran minyatürlerini betimleyen minyatürlerde hükümdarlar başlarında biçimleri itibariyle tam ispatı olmasa da taçlar taşımıştır. Bu minyatürlerde ayrıca hükümdarlar dışında melekler ve özellikle Miraç'ta Peygamberin ve Burak'ın başında bulunmaktadır. ${ }^{72}$ Türkler ile İranlıların yakın coğrafyada yaşıyor olmaları, iki kültürün birbirini etkilediği görüşünü ortaya koymuştur. Bu açıdan İran kıyafetleri ile Türk kıyafetleri arasında pek bir fark oluşmamıştır, hatta benzerlik göstermiştir. İran ve Selçuklu dönemindeki bu benzerlik sadece kıyafetlerde değil aynı zaman da sanat eserlerinde de üslup özellikleri bakımından izlenmektedir. XIII. yüzyılda kaleme alınan minyatürlerle zenginleştirilen Reşidûddin'in "Camiüt-tevarih" adlı eseri kıyafet tarihimiz açısından _önemlidir. ${ }^{73}$ Topkap1 Sarayı Müzesi'nde bulunan "Camiüt-tevarih" adlı esere ait minyatürlerin birinde Dede Korkut hikâyelerinde geçen Oğuz Han'ın yaşamıyla ilgili bir sahnede Oğuz Han'ın başlığının taç şeklinde olduğu görülmektedir (Bkz. Fotoğraf 9).
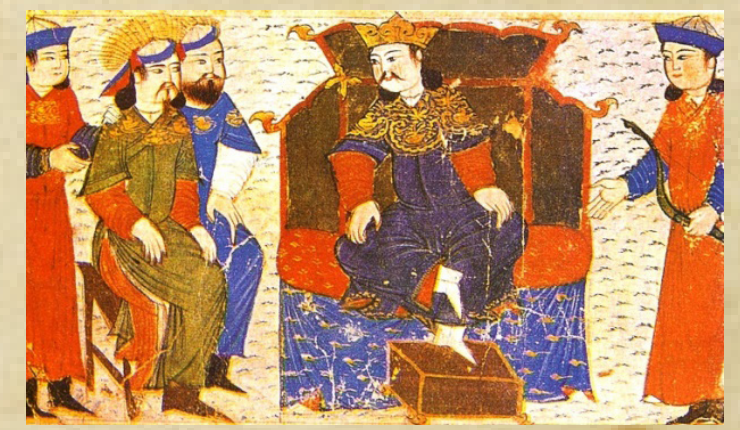

Fotoğraf 9: "Camiüt-tevarih" minyatürlerinde Oğuz Han tasviri ${ }^{74}$

Hristiyanlık kültüründe taç çok eski dönemlerden itibaren kraliyet ve saygınlık sembolüdür. Aynı zamanda krallık ve egemenlik simgesi olmuştur. Hristiyan sanatında ise cennetin kraliçesi olarak yorumlanan Meryem'in başında tasvir edilmiştir. Taç ikonografik açıdan acı çekmeyi, günah ve ölüm ile azizlerin asil kanını temsil etmiştir. Dikenli tacın Hz. İsa'nın başına geçirilmesi ve çarmıha gerilirken çektiği acılar, stigmata Hristiyanlık ikonografisinde sıklıkla rastlanmaktadır. Bazı zamanlar daire şeklinde tasarlanmıştır ve bunlarda çeşitli bitkisel donatıları olduğu kadar değerli mücevher ve altın kullanılan örnekleri de bulunmaktadır. ${ }^{75}$ Bizans imparatorları önceleri başlarına bezden bir bant bağlamıştır. IV. yüzyıldan sonra "stephanos" dedikleri tacı takmaya başlamıştır. Bu başlığı daha sonra geniş ve yanlarında incili, mücevherli pandantiflerin sarkıtıldığı başka türde taçlar izlemiştir. Buna da "stemma" adı verilmiştir. İmparatoriçelerin de taktı̆̆ bu başlık ve daha önce görülen tipler genelde törenlerde kullanılmıştır. ${ }^{76}$ Diadem adı verilen başı bir bant gibi saran üzeri mücevher kakmalı Bizans tacı şeref ve asaletin simgesi sayılmıştır. ${ }^{77}$

Osmanlı nakkaşlarının yaptığı minyatürlerde padişahın ve devlet görevlilerinin tasvir edildiği tasvirlerde başlık üzerinde taç gibi Batılı bir sembol görmek mümkün değildir. Ancak,

72 Walther Björkman, “Tac.” İslam Ansiklopedisi, c.XI (İstanbul: Milli Eğitim Basımevi, 1979), 613.

73 Türkoğlu, Tarih Boyunca Anadolu’da, 138.

74 Türkoğlu, Tarih Boyunca Anadolu'da, 138.

75 George Ferguson, Signs\&Symbols in Christian Art. (London: Oxford University Press, 1972), 166.

76 Türkoğlu, Tarih Boyunca Anadolu'da, 121.

77 Georg Ostrogorsky,“Bizans İmparatoru ve Hiyerarşik Dünya Düzeni.” Cogito 17 (1999), 54. 
XVI. yüzyılda Osmanlı'da bulunan Moryson'un hatıratlarında, çavuştan sultana kadar bütün resmi görevlilerin tülbentlerinin tepelerinde kırmızı kadife bir taç bulunduğunu, rütbelerini belirten tüy ve mücevherlerin buna takıldığını anlatmıştır. ${ }^{78} \mathrm{Bu}$ durum aslında sarığın iç bölümünde bulunan kadife kırmızı başlığın taç olmamasına rağmen Batılılar tarafından taç şeklinde yorumlandığının göstergesidir.

Osmanlı devletine Batıdan gelen sanatçılar bu geleneği devam ettirmeye çalışsa da kendi kültürlerinden sembolik izleri eserlerine taşımıştır. Gentile Bellini’nin 1480 yılında yapmış olduğu Sultan II. Mehmed'i tasvir eden portresine bakıldığında sarığının iç tarafında kırmızı kadifeden bir başlık yer almaktadır ancak bu bir taç değildir. Sultan II. Mehmed'in tablo ve madalyonunda görülen sarık tipi budur. Ancak bunun yanında Bellini, tablosunda üst sağ ve sol köşede Osmanlı hâkimiyeti altında birleştiği düşünülen üç hükümdarlığın Asya, Yunanistan ve Trabzon devletlerinin remzi olan üst üste üç taç betimlemiştir (Bkz. Fotoğraf 10), dolayısıyla bu tablonun Batılı bir sanatçı tarafından yapıldığı kolayca anlaşılmaktadır. ${ }^{79}$

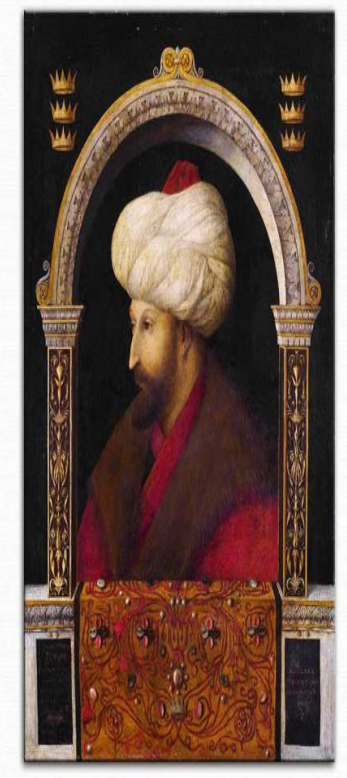

Fotoğraf 10: Gentile Bellini’nin yaptığı Sultan II. Mehmed portresi (National Gallery, Londra $)^{80}$

Tahsin Öz, Osmanlı kumaşlarında sevilerek kullanılan renkler arasında ilk sırada kırmızının geldiğini ifade etmiştir. Milli bir renk olarak Türk kırmızısından bahsetmiştir. Bundan sonra mavi, yeşil, beyaz, bej, siyah ve bazı yerlerde altın rengini temsilen sarının tercih edildiğini söylemiştir. Ona göre, XIV. yüzyıldan itibaren Osmanlı süslemelerine bakıldığında da bunlar beş gruba ayrılmıştır:

80 Massimo Villa, "Gentile E La Politica Del "Sembiante" A Stambul. haz. Carlo Pirovano, Venezia e $i$ Turchi (Milano: Electa Editrice, 1985), 165. 
1. Bitkisel motifler; bunlar kendi içinde üç çeşittir.

a) Çiçekler; lale, karanfil, sümbül, gül, şakayık, çark-1 felek, narçiçeği, erik çiçeği ile çeşitli yapraklar

b) Meyveler; nar, elma, çam kozası

c) Ağaçlar; servi, hurma, zülfüarus (şükela)

2. Kozmik motifler; güneş, ay, yıldız

3. Yabancı kökenli motifler; taç, meandır

4. Zoomorfik figürler

5. Çeşitli yazılar.

Tahsin Öz, makalesinin devamında yabancı kökenli motifler ile ilgili olarak Türk sanatçısının mutaassıp olmadığını yeri geldiğinde taç ve meandır gibi motifleri eserlerinde kullanabildiğini söylemiştir. ${ }^{81}$

Bu konuya geç bir dönem olsa da 1863 yılında Arif Mehmed Paşa'nın (1808-1865) yazıp resimlediği "Мeсти'a-i Tesavir-i Osmaniye" adlı eser örnek verilebilir. Osmanlı Devleti'nin kuruluşundan itibaren başladığı resimlerden ilki Osman Gazi'ye aittir. Sonrasında ise kendi döneminden Sultan II. Mahmud ile devam etmiştir. Arif Mehmed Paşa'nın resimleri Batı resim geleneğine daha yakın bir üsluptadır. ${ }^{82}$ (Bkz. Fotoğraf 11). Osman Gazi’nin tasvir edildiği minyatüre bakıldığında sarık biçimli başlığının orta bölümünün taçlı olduğu gözlenmektedir. Yabancı kökenli bir imgenin kullanılmasıyla ilgili bu örnek Osmanlı'nın Batılılaşma sürecindeki kültürel etkileşim boyutunu ortaya koymaktadır.

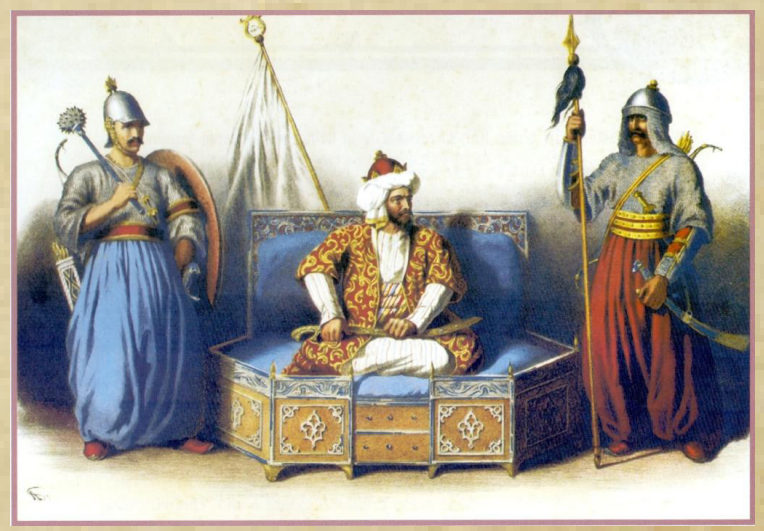

Fotoğraf 11: Arif Mehmed Paşa'nın "Mecmu'a-i Tesavir-i Osmaniye" eserindeki Osman Gazi betimlemesi ${ }^{83}$

81 Tahsin Öz, “Osmanlı Devrinde Resimli Türk Kumaşları”. V. Türk Tarih Kongresi (Ankara: Türk Tarih Kurumu Yayınları, 1956), 446-447.

82 Şahin Tekinalp, “Geleneğin Devamı:Bahriyeli”, 218.

83 Anonim, Osmanlı Resmi Kıyafetleri Albümü “Mecmu’a-i Tesavir-i Osmaniye.” (İstanbul: Çamlıca Basın Yayım ve Tic. A.Ş.), 7. 
XV. yüzyıldan itibaren betimlenen Osmanlı padişahlarının anatomik açıdan karakteristik yüz yapılarından bahsetmek mümkündür. Angiolello, Sultan II. Mehmed'i etli butlu, geniş alınlı, iri gözlü, gür kaşlı, kemerli burunlu, küçük ağızlı, gür sakallı, kısa ve kalın boyunlu bir adam olarak tanımlamıştır. ${ }^{84} \mathrm{Bu}$ tanımlamaya uygun olarak Costanzo da Ferrara (1481) (Bkz. Fotoğraf 12), Giovanni, Bertoldo (1480-1481) (Bkz. Fotoğraf 13) ve Gentile Bellini’nin (1490) (Bkz. Fotoğraf 14) yaptığı bronz madalyonlara bakıldığında Sultan II. Mehmed'in kemerli bir buruna sahip, sakallı, kısa ve kalın boyunlu bir yapıda olduğu anlaşılmaktadır. Osmanlı'da "irsâl-i lihye" adı verilen sakal bırakma önemlidir. Sakal bırakan kişiler olgun, ağırbaşı, uslu, akıllı bir adam sayılmıştır ve gençlerce hürmet gösterilmiştir. Sakalı yeni çıkmaya başlayan gençler arasında çıktığı kadarıyla bırakma geleneği vardır. Sakal bırakmayanlar da "böyle iç ăgası gibi bıyıkla gezmek yakışır mı?" diye ayıplanmıştır. İlmiye sınıfındaki gençler asla tıraş olmamış ve sakal bırakmıştır. ${ }^{85}$

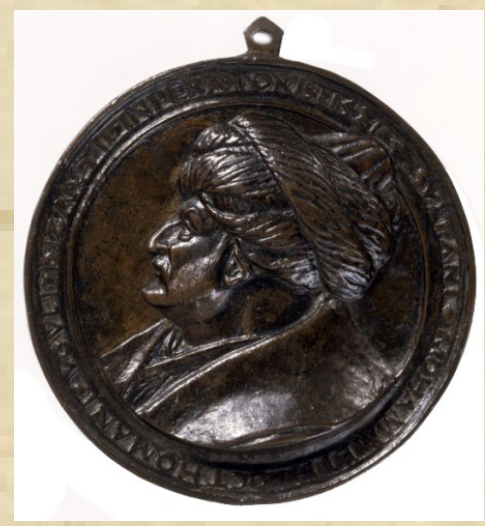

Fotoğraf 12: Costanzo da Ferrara’nın yaptığı (1481) Sultan II. Mehmed tasvirli madalyon ${ }^{86}$

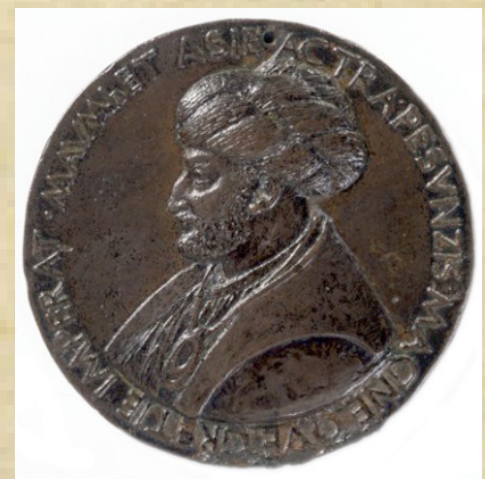

Fotoğraf 13: Giovanni, Bertoldo'nun yaptığı (1480-1481) Sultan II. Mehmed tasvirli madalyon $^{87}$

84 Giampiero Bellingeri, "İmgelere Kavuşmak." haz. Giampiero Bellingeri ve Nazan Ölçer, Osmanlı Döneminde Venedik ve İstanbul (İstanbul: Electa, 18 Kasım 2009-28 Şubat 2010), 87.

85 Abdülaziz Bey, Osmanlı Adet, Merasim, 98.

86 "Mehmed II" erişim 14 Mart 2021, http://m.vam.ac.uk/item/O142591/mehmed-ii-medal-costanzo-daferrara

87 "Mehmed II" erişim 14 Mart 2021, http://m.vam.ac.uk/item/O134080/mehmed-ii-medal-di-giovannibertoldo/ 


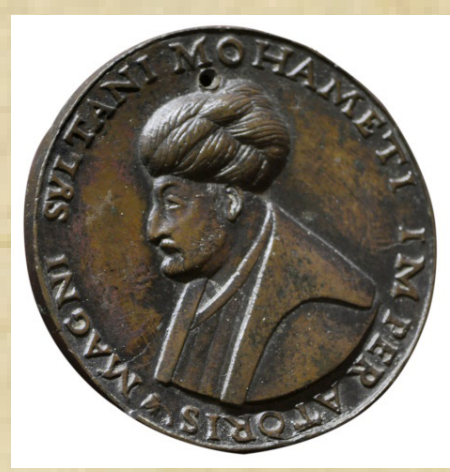

Fotoğraf 14: Gentile Bellini'nin yaptığ (1490) Sultan II. Mehmed tasvirli madalyon (Museo Correr, Venedik) $^{88}$

Gentile Bellini tarafından yapıldı̆̆ı iddia edilen ve İstanbul Büyükşehir Belediyesi tarafından 2020 yılında satın alınan Sultan II. Mehmed ile bir diğer kişiye ait portre tabloda Sultan'ın Bellini tarafindan çizilen diğer tablosu ve madalyonunda görülen portresine fizyolojik ve giyim açısından benzerlik gösterdiği ifade edilebilir. (Bkz. Fotoğraf 10 ve Fotoğraf 15) Sarığının tepesinde kırmızı renkteki kadife tepeliği görülmektedir. Karşısında duran kişinin kim olduğuna dair birçok fikir ortaya konmuştur. Bu kişinin sarığının bir ucu üst tarafta yukarıya doğru uzatılmış bir şekilde betimlenmiş olması yanında kırmızı kadife yerine koyu renkte bir tepeliğe sahip başlığının olduğu görülmektedir. Ayrıca sarığının arkasında yedi adet sorguç tüyü yer almaktadır. Bunun yedi adet olmasının sembolik bir anlamının olup olmadığını yorumlamak çok güç ancak Sultan II. Mehmed'in Osman Bey'den itibaren Osmanlı Devleti'nin yedinci padişahı olması belki de bu duruma bir gönderme özelliği taşıdığı söylenebilir. Bu kişinin fizyolojik açıdan yüz hatları oldukça naiftir. Kaftanı ise Sultan II. Mehmed'in giydiğine göre motif işlemelidir. Bu açılardan değerlendirildiğinde Batılı bir kişiye ait portre olma ihtimali bulunmaktadır.

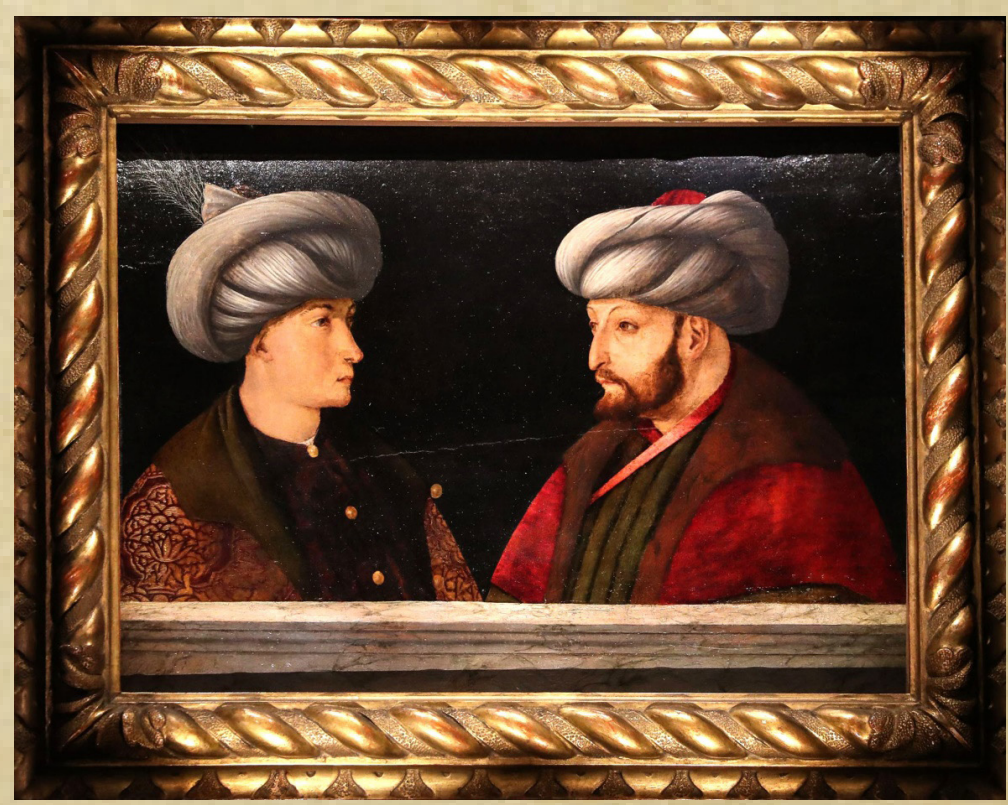

Fotoğraf 15: İstanbul Büyükşehir Belediyesi tarafından satın alınan Sultan II. Mehmed portresi $^{89}$ 
XVI. yüzyılda çizilmiş Barbaros Hayreddin Paşa’nın Batılılar tarafından çizilen gravüründe güçlü, heybetli, kararlı, dik bakışlı, sakallı, kısa ve kalın boyunlu, kemerli bir buruna sahip Osmanlı Kaptan-1 Derya'sı tasvir edilmiştir. Kaftanı ve üzerindeki motifler Osmanlı kültürel izlerini taşımaktadır. Ancak sarığına bakıldığında tepesinde yer alan takkede bir taç görülmektedir (Bkz. Fotoğraf 16). Aynı yüzyıl içinde Nigãrî tarafindan çizilmiş Barbaros Hayreddin Paşa'nın yaşlılık yıllarını gösteren yarım boy minyatür portrede bir elinde asasını tutarken diğer eliyle karanfili koklamaktadır ${ }^{90}$ ve sarığının Batılı gravürden farklılık gösterdiği anlaşılmaktadır. (Bkz. Fotoğraf 17).

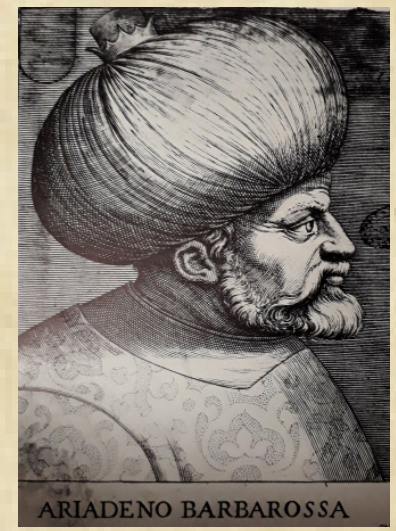

Fotoğraf 16: Barbaros Hayreddin Paşa, XVI. Yüzy1l, Floransa Biblioteca Nazionale Cenrtale $^{91}$

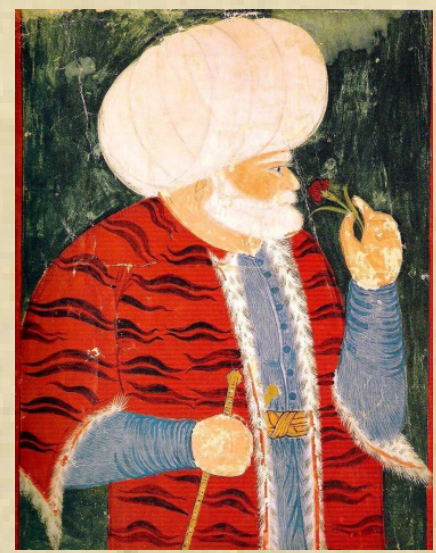

Fotoğraf 17: Nigãrî tarafından çizilmiş Barbaros Hayreddin Paşa minyatürü ${ }^{92}$

1596 yilında Giacomo Franco tarafindan çizilen ve Sultan III. Mehmed'i tasvir eden gravüre bakıldığında sağ kulağında halka küpesi bulunan, sağ elinde hilal motifli başlığı bulunan bir asa tutan, kaftan yerine ceketinin üzerini örten üzerinde kıvrımlı akantus dallarına ait bitkisel süslemeler bulunan bir pelerin taşıyan, yukarıya doğru burma bıyıklı, top sakallı, ince yüzlü naif bir

portresi-ziyarete-acildi/

90 Serpil Bağcı, Filiz Çağman, Günsel Renda ve Zeren Tanındı, Osmanlı Resim Sanatı. (Ankara: Kültür ve Turizm Bakanlığı, 2006), 85.

91 Alberto Tenenti,"Profilo di un Conflitto Secolare.” haz. Carlo Pirovano, Venezia e $i$ Turchi (Milano: Electa Editrice, 1985), 28.

92 Bağcı, Çağman, Renda ve Tanındı, Osmanlı Resim Sanatı, 84. 
Osmanlı padişahı görülmektedir. Sultan IV. Mehmed için bu anatomik yüz tipi dönemin Batılı diğer gravür sanatçıları tarafindan genellikle benzer karakterde çizilmiştir. İlgi çeken detay başlığıdır ve sarık veya kavuğunun tepe bölümünde yine bir taç yer almaktadır. Kavuğunun önünde ortasında değerli bir taş olduğu düşünülen rozet vardır ve sağ üst taraftan aşağıya doğru tüyler sarkıtılmıştır. Osmanlı' da ise Nakşî’nin 1600 yılları civarında çizdiği Sultan III. Mehmed'in Eğri Kalesi önlerinde betimlendiği düşünülen minyatüründeki detaylı tasvirine bakıldığında (Bkz. Fotoğraf 19) Giacomo Franco tarafından gravüre çizilen diğer örneğiyle ne kadar farklılıklar içerdiği görülecektir.

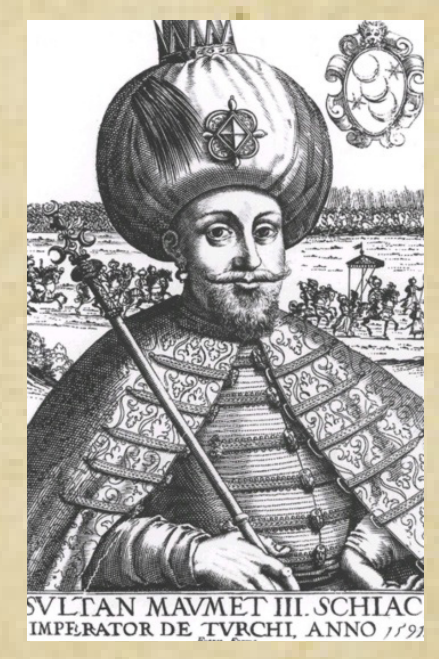

Fotoğraf 18: 1596 yılında Giacomo Franco tarafindan çizilen Sultan III. Mehmed gravürü ${ }^{93}$

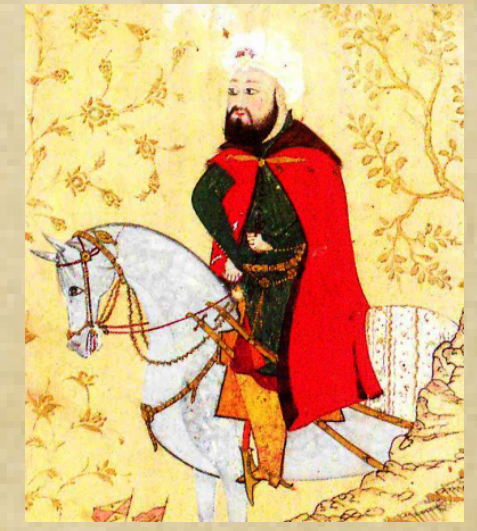

Fotoğraf 19: Nakş̂̂’nin 1600 yılları civarında çizdiği Sultan III. Mehmed tasviri (detay) $)^{94}$

Yaklaşık olarak 1648-1700 yıllarına tarihlendirilen sanatçısı bilinmeyen ve yine oryantalist etkilerin yoğun bir şekilde hissedildiği gravürde Sultan IV. Mehmed tasvir edilmiştir. Sağ elinde asa başı hilal şeklinde olan bir asa bulunmaktadır. Kürklü pelerin ve altında yine batı kökenli motiflerin yer aldığı giysisi vardır. Kürklü pelerinin yakası değerli taşlarla süslü bağ ile birleştirilmiştir. Her iki kulağında ters hilâl biçimli küpeleri bulunur. Anatomik yüz tipi olarak ince narin bir yapıdadır, sakalsız ve ince bir bıyığa sahiptir. Sarık veya kavuğunun ortasında değerli taşlarla süslü bir sorguç yer alır ve sorguçtan çıkan inci dizileri başlı̆̆ sarmıştır. Tepede akantus yapraklarına benzer bir süsleme görülmektedir ve yine sorgucun arkasında tepelikle birlikte taç betimlenmiştir (Bkz:

93 Tenenti,"Profilo di un”, 104.

94 Bağcı, Çağman, Renda ve Tanındı, Osmanlı Resim Sanatı, 220. 
Fotoğraf 20). Sultan IV. Mehmed "tac-ı sultanı̂" adı verilen kavuk giymiştir. Bunun ön kısmında bir sorgucu vardır. Kıyafet olarak üstüne yeşil zeminli kolları beyaz üstüne kırmızı baklava şeklinde üzeri altın sırma işlemeli, göğsü altın sırma kordon ve püsküllü üstlük kullanmıştır. ${ }^{95}$

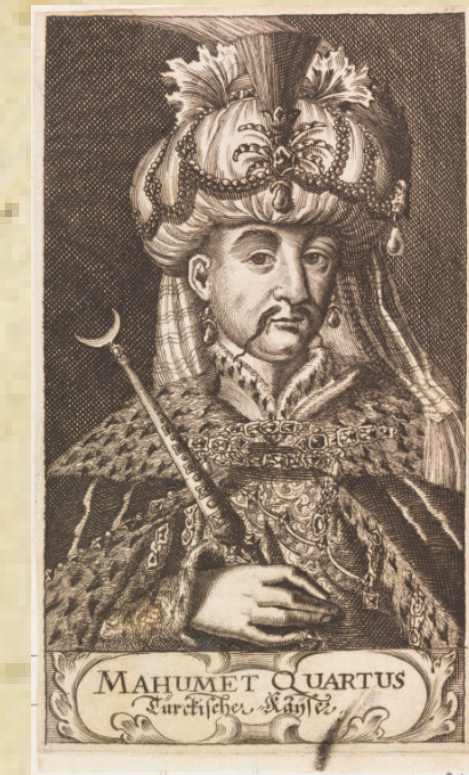

Fotoğraf 20: Sultan IV. Mehmet tasvirli gravür (Victoria ve Albert Museum) ${ }^{96}$

XVIII. yüzyılda başlarında Étienne Jehandier tarafından Sultan III. Ahmed'in portresi gravüre yapılmıştır. Oryantalist etkilerin yoğun olarak sezildiği gravürde Sultan III. Ahmed yine naif bir görüntüde betimlenmiştir. Pelerinin de akantus dallarına ait motifler görülmektedir. Aynı zamanda hem pelerinin yakasında hem de sarık veya kavuğunun üstünde değerli mücevherlerin yanında inci dizileri yer almaktadır. Sarığının tepesinde bulunan taç yine dikkati çekmektedir (Bkz. Fotoğraf 21). Osmanlı'da Batılılaşma dönemi olarak adlandırılan sanatta ve sosyo-kültürel anlamda birçok alanda yeniliklerin yaşandığı bu dönem minyatürlerine damgasını vuran nakkaş Levnî'dir. Onun erken devir çalışmalarını içeren Osman Gazi'den Sultan III. Ahmed'e kadar 23 padişahın portresini çizdiği “Kebir Musavver Silsilenâme”de dönemin padişahı Sultan III. Ahmed'in tasviri yer almaktadır. Padişah yüksek arkalıklı tahtında oturmaktadır ve hemen yanında ayakta şehzadesi durmaktadır. Tahtın üzerinde lale ve sümbül gibi dönemin sevilen bitkisel motifleri yapılmıştır. Şehzade ile padişahın kaftanları içli dışlı olarak birbiriyle benzerlik göstermektedir. ${ }^{97}$ Başlıkları yanlardan "V" şekli oluşturan kaval silmeli yüksek kavuk niteliğindedir ve padişahın kavuğunda mücevherlerle donatılmış ihtişamlı sorgucu betimlenmiştir (Bkz. Fotoğraf 22).

95 Emin Cenkmen, Osmanlı Sarayı ve Klyafetleri (İstanbul: Türkiye Yayınevi, 1948), 45.

96 “Turkish Sultans, Sultanas” erişim 14 Mart 2021, http://m.vam.ac.uk/item/O515451/turkish-sultanssultanas-and-other-print-unknown/

97 Bağcı, Çağman, Renda ve Tanındı, Osmanlı Resim Sanatı, 262-263. 


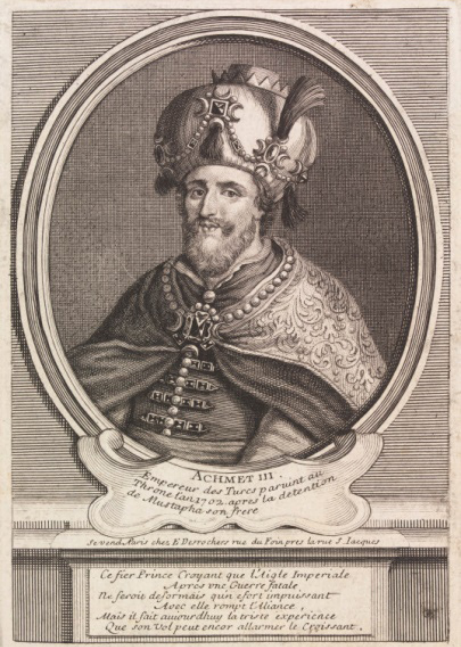

Fotoğraf 21: Étienne Jehandier tarafından çizilen Sultan III. Ahmed gravürü (Victoria ve Albert Museum $)^{98}$

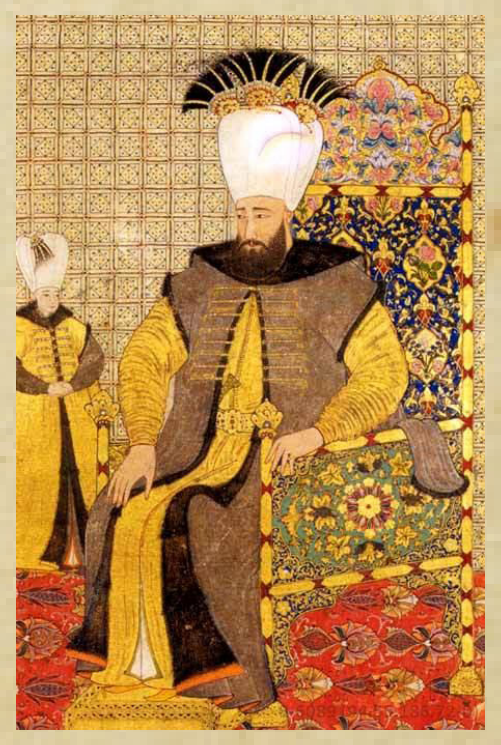

Fotoğraf 22: Levnî’nin çizdiği Sultan III. Ahmed tasviri ${ }^{99}$

1340’lı yıllardan XVI. yüzyılın sonlarına kadar birçok Türk-Osmanlı elçisi İtalya ve Fransa saraylarını ziyaret etmiştir. Kıyafet ve adetleri büyük merak uyandırmıştır. Bu ziyaretler sonucunda da bu ülkelerde yüksek çevrelerde Türk modası "alla turca, turquerie" başlamıştır. 1721 yılında Yirmisekiz Mehmed Çelebi’nin elçiliği Paris’te Türk modasının yayılmasına büyük katkı sağlamıştır ${ }^{100}$. Sultan III. Selim ise Moralı Seyyid Ali Efendi’yi üç yıl süreliğine Fransa'ya elçi olarak atamıştır ve sefirin Paris’te gerek hükümet erkânı gerekse halk arasında itibar görmesi ve

98 “Turkish Sultans, Sultanas”, erişim 14 Mart 2021, http://m.vam.ac.uk/item/O515454/turkish-sultanssultanas-and-other-print-desrochers-etienne-jehandier/

99 Bağcı, Çağman, Renda ve Tanındı, Osmanlı Resim, 262.

100 Halil İnalcık, Osmanlılar, Fütühat, Imparatorluk, Avrupa İle İlişkiler (İstanbul: Timaş Yayınları, 2010), 248. 
özel davetlerde aranan popüler bir şahsiyet kazanması neticesinde Türk kıyafetleri geniş çevrelerde modaya hâkim bir konuma gelmiştir. ${ }^{101}$ Padişahlar, İstanbul' daki yabancı devlet sefirlerine kaftan armağan etmiştir. Heyetler açısından alınan kaftanların sayısı ve kalitesi önemlidir çünkü buna göre görevlerinin iyi veya kötü sonuçlanacağını tahmin etmişlerdir. ${ }^{102}$

\section{Sonuç}

Avrupa'nın çeşitli müzelerinde bu araştırmaya konu olan sayısız Türk imgeli eser bulunmaktadır. Bu eserler ilgili müzelerin uzmanları tarafından değerlendirilerek sergi salonlarında sergilenmekte ve ziyaretçilere bu bilgiler Türk kimliği altında paylaşılmaktadır. Bu araştırmada Orta Asya'dan itibaren genel itibariyle Türk İmgesi'ne Avrupa penceresinden de bakılmış ve Avrupa'nın Osmanlı'yı kendi düşünceleri üzerinde korku duyulan bir millet özelinden oryantalist etkilerle şekillendirmeye çalıştığı özel ilgisine dönüşmüştür. Türk kimliği Orta Asya'dan itibaren hem fizyolojik hem de giyim kuşam bağlamında belli bir karakteri yansıtmaktadır. Ancak Avrupa'da bulunan ve çeşitli müzelerde Türk adıyla tanımlanmış birçok sanat eserinde yansıtılan portrenin empresyonist ve oryantalist etkiler altında yapıldığı söylenmelidir. Bunun yanında özellikle XVIII. yüzyılda Avrupa'da doruk noktasına çıkan "Turquerie" modası kapsamında Avrupalı kişiler de kendilerini Osmanlı padişahı gibi tasvir ettirmiştir. Bu açıdan Tük kıyafeti içinde betimlenmiş her figürün de Türk veya Osmanlı olarak yorumlanması bu açıdan hatalı bir söylemdir.

\section{Kaynakça}

Abdülaziz Bey. (1995). Osmanlı Adet, Merasim ve Tabirleri. (K. Arısan, ve D. Arısan Günay, Dü) İstanbul: Tarih Vakfi.

Acıpınar, M. (2010). XVII. Yüzyılın İlk Yarısında Toskana Grandukalığında Türk Esirler. Tarih Incelemeleri Dergisi, XXV(1), 15-38.

Anonim. (tarih yok). Osmanlı Resmi Klyafetleri Albümü “Mecmu'a-i Tesavir-i Osmaniye”. İstanbul: Çamlıca Basın Yayım ve Tic. A.Ş.

Arık, R. (2000). Kubad Abad. İstanbul: Türkiye İş Bankası.

Bağcı, S., Çağman, F., Renda, G., ve Tanındı, Z. (2006). Osmanlı Resim Sanatı. Ankara: Kültür ve Turizm Bakanlığı.

Başkan, S. (2000). Sanat ve Tarih. Ankara: Çardaş Yayıncılık.

Begiç, H. N. (2016). Giyim-Kuşam Kültüründe Keçe Sanatına Tarihsel Bir Bakış, Selçuk Üniversitesi Türkiyat Araştırmaları Dergisi, 40, 287-297

Begiç, H. N. (2017). Türk Keçecilik Sanatı. Ankara: Atatürk Kültür Merkezi Başkanlığı

Bellingeri, G. (18 Kasım 2009-28 Şubat 2010). İmgelere Kavuşmak. G. Bellingeri, ve N. Ölçer içinde, Osmanlı Döneminde Venedik ve Ístanbul (s. 86-96). İstanbul: Electa.

Berkli, Y. (2010, Aralık). Uygur Resim Sanatının Üslup Özellikleri. Atatürk Üniversitesi Edebiyat Fakültesi Sosyal Bilimler Dergisi, 10(45), 155-166.

101 Unat, Osmanlı Sefirleri ve, 180.

102 Lale Görünür ve Semra Ögel, "Osmanlı Kaftanları İle Entarinin Farkları ve Kullanışları.” İTÜ Sosyal Bilimler Dergisi, 3/1 (2006), 66. 

Basımevi.

Björkman, W. (1967). Sarık. İslam Ansiklopedisi, X, 221-233. İstanbul: Milli Eğitim

Björkman, W. (1979). Tac. İslam Ansiklopedisi, XI, 613-615. İstanbul: Milli Eğitim Basımevi.

Cenkmen, E. (1948). Osmanlı Sarayı ve Klyafetleri. İstanbul: Türkiye Yayınevi.

Çal, H. (2000). İstanbul Eyüp’teki Erkek Mezar Taşlarındaki Başlıklar. Tarihi, Kültürü ve Sanattyla III. Eyüp Sultan Sempozyumu, (s. 207-225). İstanbul.

Çetin, Ö. H. (2016). Onyedinci Yüzyıla Ait Kıyafet Albümlerinde Osmanlı Erkek GiyimKuşamı. The Journal Of Academic Social Science (53), 259-264.

Durmuş, İ. (2017). Türk Adının Ortaya Çıkışı, Anlamı ve Yayı1ışı. Akademik Bakış, 10(20), 37-47.

Erkan, T. (2010). Anadolu Selçuklu Sanatındaki İnsan Figürlerinin Uygurların Mağara Resimleri ve Gaznelilerin Duvar Resimleriyle Konu ve Biçim Yönünden Karşılaştırılması. Turkish Studies, 5(3), 1218-1263.

Esin, E. (1978). İslamiyetten Önceki Türk Kültür Tarihi ve İslama Giriş. İstanbul: Edebiyat Fakültesi Matbaasi.

Ferguson, G. (1972). Signs\&Symbols in Christian Art. London: Oxford University Press.

Galland, A. (1998a). İstanbul`a Ait Günlük Hatıralar(1672-1673) (Cilt I (1672)). (C. Schefer, Dü., ve N. Örik, Çev.) Ankara: Türk Tarih Kurumu.

Galland, A. (1998b). İstanbul`a Ait Günlük Anılar (1672-1673) (Cilt II (1673)). (C. Schefer, Dü., ve N. Örik, Çev.) Ankara: Türk Tarih Kurumu.

Gömeç, S. (1997). Uygur Türkleri Tarihi ve Kültürü. Ankara: Atatürk Kültür, Dil ve Tarih Yüksek Kurumu.

Görünür, L., ve Ögel, S. (2006). Osmanlı Kaftanları İle Entarinin Farkları ve Kullanışları. İTÜ Dergisi Sosyal Bilimler, 3(1), 59-68.

İnalcık, H. (2010). Osmanlılar, Fütühat, Imparatorluk, Avrupa İle İlişkiler. İstanbul: Timaş Yayınları.

İskenderzade, L. (2010). Göktürk Dönemi İnsan Figürlü Taş Anıtları. Selçuk Üniversitesi Sosyal Bilimler Enstitüsü Dergisi(24), 255-269. Kurumu.

İzgi, Ö. (1989). Çin Elçisi Wang Yen-Te'nin Uygur Seyahatnamesi. Ankara: Türk Tarih

Karcaubay, S., ve Karcaubay, C. (2013, Ocak 1). Göktürk'ün Toprak Halkı. Atlas Dergisi(I), $62-76$

Kazıcı, Z. (2007). İslam Devletlerinin Zimmi Tebeaya Bakışı (Osmanlı Örneği). Kur'an-l Kerim'de Ehl-i Kitab Tartışmalı Illmi Toplantı, (s. 306-324). İstanbul.

Koca E., Koç F. (2014). Kıyafetnameler ve Ralamb'ın Kıyafet Albümün'deki 17. Yüzyı1 Osmanlı Toplumu Giysi Özelliklerinin İncelenmesi. Turkish Studies, 9(11), 371-394

Koçu, R. E. (1967). Türk Giyim Kuşam ve Süslenme. Ankara: Sümerbank Kültür Yayınları. 
Köymen, M. (1971). Alp Arslan Zamanı Türk Giyim Kuşamı. Selçuklu Araştırmaları Dergisi, 51-89.

Marchetti, S. (2005). Avrupalıların Gözüyle Türkler:Mitos ve Yanlış Anlaşılma. Ö. Kumrular içinde, Dünyada Türk Imgesi (s. 9-12). İstanbul: Kitap Yayınevi.

Orazbay, M. (1993). Çin Kaynaklarına Göre Esli Türk Kitabeleri. İ. Ateş, S. Bayram, ve M. Narince içinde, X. Vakıf Haftası Kitabı (s. 67-69). Ankara: Vakıflar Genel Müdürlüğü Yayınları.

Ostrogorsky, G. (1999). Bizans İmparatoru ve Hiyerarşik Dünya Düzeni. Cogito(17), 51-68.

Öz, M. (2008). Tarihi Perspektiften Türk Kimliği Üzerine Bazı Düşünceler. Hacettepe Üniversitesi Türkiyat Araştırmaları (HÜTAD)(8), 219-226.

Öz, T. (1956). Osmanlı Devrinde Resimli Türk Kumaşları. T. T. Kurumu içinde, V. Türk Tarih Kongresi (s. 442-452). Ankara: Türk Tarih Kurumu Yayınları.

Özkeçeci, İ. (2011). Orhun Abidelerinin Estetik ve Muhtevasının Önemi. Ü. Çelik Şavk (Dü.), III. Uluslararası Türkiyat Araştırmaları Sempozyumu içinde, II, s. 653-668. Ankara.

Öztuna, Y. (2006). Cumhuriyet Dönemi Öncesinde Türkler. İstanbul: Babıali Kültür Yayıncılı̆̆ı.

Papila, A. (2008). Osmanlı_Imparatorluğu nun Batılılaşma Döneminde Resim Sanatının Ortaya Çıkışı ve Osmanlı Kimliğinin Resimsel Anlatımı. Gazi Üniversitesi Sanat ve Tasarım Dergisi, 117-134.

Raby, J. (2006). La Serenissime et la Sublime Porte: les arts dans l'art diplomatique. Y. Guena içinde, Venise et l'Orient 828-1797 (s. 91-120). Paris: Editions Gallimard.

Reyhanlı, T. (1983). İngiliz Gezginlerine Göre XVI. Yüzyılda İstanbul〉da Hayat. Ankara: Kültür ve Turizm Bakanlığı Yayınları. Merkez.

Süslü, Ö. (2007). Tasvirlere Göre Anadolu Selçuklu Kıyafetleri. Ankara: Atatürk Kültür

Şahin Tekinalp, P. (2014, Haziran). Geleneğin Devamı:Bahriyeli Ressam Hüsnü Tengüz’ün Kiyafet Albümü. Hacettepe Üniversitesi Edebiyat Fakültesi Dergisi, 31(1), 207-220.

Taneri, A. (1977). Türkiye Selçukluları Kültür Hayatı. Konya: Akın Basımevi.

Taşağıl, A. (1996). Bilge Kağan 'ın Vasiyeti. İstanbul: Turan Yayıncılık.

Taşağıl, A. (2015). Kök Tengri’nin Çocukları. İstanbul: Bilge Kültür Sanat.

Tekinoğlu, H. (2015). Uygurlar. İstanbul: Kamer Yayınları.

Tenenti, A. (1985). Profilo di un Conflitto Secolare. C. Pirovano içinde, Venezia e i Turchi (s. 9-37). Milano: Electa Editrice.

Tezcan, H. (1999). Topkapı Saray Müzesi Giyim Kuşam Koleksiyonu Saray Kıyafetleri. E. Güler içinde, Osmanlı Ansiklopedisi "Kültür ve Sanat” (Cilt XI, s. 515-528). Ankara: Yeni Türkiye Yayınları.

Tunç, Ş. (2010). Şehristan Seyyahların Hayal Şehri İstanbul. İstanbul: İstanbul Ticaret Odası.

Türkoğlu, S. (2002). Tarih Boyunca Anadolu'da Giyim Kuşam (Cilt I). İstanbul: Atılım Kağıt 
Ürünleri ve Basım.

Unat, F. (1968). Osmanlı Sefirleri ve Sefaretnameleri. (B. Baykal, Dü.) Ankara: Türk Tarih Kurumu.

Villa, M. (1985). Gentile E La Politica Del "Sembiante" A Stambul. C. Pirovano içinde, Venezia e i Turchi (s. 160-185). Milano: Electa Editrice.

İnernet Kaynakçası

"Mehmed II" erişim 14 Mart 2021, http://m.vam.ac.uk/item/O142591/mehmed-ii-medalcostanzo-da-ferrara

"Mehmed II" erişim 14 Mart 2021, http://m.vam.ac.uk/item/O134080/mehmed-ii-medaldi-giovanni-bertoldo/

"Fatih Sultan Mehmed" erişim 26.04.2021, https://dokuz8haber.net/kultur-sanat/fatihsultan-mehmetin-portresi-ziyarete-acildi/

“Turkish Sultans, Sultanas” erişim 14 Mart 2021, http://m.vam.ac.uk/item/O515451/turkishsultans-sultanas-and-other-print-unknown/

“Turkish Sultans, Sultanas”, erişim 14 Mart 2021, http://m.vam.ac.uk/item/O515454/turkishsultans-sultanas-and-other-print-desrochers-etienne-jehandier/ 